\title{
Planktonic associations between medusae (classes Scyphozoa and Hydrozoa) and epifaunal crustaceans
}

\author{
Kaden Muffett ${ }^{\text {Corresp., }}{ }^{,}$, Maria Pia Miglietta ${ }^{1}$ \\ ${ }^{1}$ Department of Marine Biology, Texas A\&M University - Galveston, Galveston, Texas, United States \\ Corresponding Author: Kaden Muffett \\ Email address: kmmuffett@tamu.edu
}

Jellyfish are known to carry various epibionts, including many of the subphylum Crustacea. However, the associations between gelatinous zooplankton and other invertebrates have been chronically overlooked. Crustacea, a massive clade of economically, ecologically, and culturally important species, includes many taxa that utilize gelatinous zooplankton for food, transport, and protection as both adults and juveniles. Here we compile 211 instances of epifaunal crustaceans recorded on Hydromedusae and Scyphomedusae from a century of literature. These include 78 identified crustacean species in 65 genera across nine orders found upon 37 Hydromedusa species and 48 Scyphomedusae. The crustacean life stage, location, nature of the association with the medusa, years, months, and depths are compiled to form a comprehensive view of the current state of the literature. Additionally, this review highlights areas where the current literature is lacking, particularly noting our poor understanding of the relationships between juvenile crabs of commercially valuable species and medusae. 
1 Planktonic associations between medusae (classes Scyphozoa and Hydrozoa) and epifaunal

2 crustaceans

3

4 Kaden McKenzie Muffett ${ }^{1}$, Maria Pia Miglietta ${ }^{1}$

5

$6{ }^{1}$ Department of Marine Biology, Texas A\&M at Galveston, TX, USA

7

8 Corresponding author:

9 Kaden Muffett ${ }^{1}$

10200 Seawolf Parkway, Galveston, TX, USA, 77554

11 Email address: kmmuffett@tamu.edu 
14

\section{Abstract}

Jellyfish are known to carry various epibionts, including many of the subphylum

Crustacea. However, the associations between gelatinous zooplankton and other invertebrates have been chronically overlooked. Crustacea, a massive clade of economically, ecologically, and culturally important species, includes many taxa that utilize gelatinous zooplankton for food, transport, and protection as both adults and juveniles. Here we compile 211 instances of epifaunal crustaceans recorded on Hydromedusae and Scyphomedusae from a century of literature. These include 78 identified crustacean species in 65 genera across nine orders found upon 37 Hydromedusa species and 48 Scyphomedusae. The crustacean life stage, location, nature of the association with the medusa, years, months, and depths are compiled to form a comprehensive view of the current state of the literature. Additionally, this review highlights areas where the current literature is lacking, particularly noting our poor understanding of the relationships between juvenile crabs of commercially valuable species and medusae.

\section{Background}

An increased focus on ocean climate research in the past twenty years has made clear the fragility of the world's oceans and the organisms that live within them. The rate at which species are disappearing, undergoing climate-related range fluctuations, and experiencing developmental and behavioral changes is unlike anything seen in the time of record (Walther et al., 2002; Guinotte \& Fabry, 2008; Comeaux, Allison \& Bianchi, 2012). Attempts to model changes in populations, species, and ecosystems have laid bare the degree to which dynamics among many marine invertebrates remain unknown and poorly understood (Uye, 2008; Brodeur, Ruzicka \& Steele, 2011; Henschke et al., 2014). This problem is especially apparent in jellyfish of the 
phylum Cnidaria, which are chronically understudied and poorly categorized (Riascos et al., 2013; Gambill \& Peck, 2014; Sweetman et al., 2016; Gómez Daglio \& Dawson, 2017). Long considered a pure pest, the last decade has demonstrated an increasing number of ways in which jellyfish are critical components of the ecosystems they reside in (Cardona et al., 2012; Hays et al., 2018). While they are best known for the vertebrates that depend on them for nutrition, including turtles and birds, they provide a host of ecosystem services unrelated to a "prey" designation. Reef and non-reef fish juveniles readily congregate around large scyphozoans, some hiding within the bell or between tentacles when disturbed (Brodeur, 1998; D'Ambra et al., 2014; Tilves et al., 2018). Large jellyfish can reach sizes that allow them to support independent encrusting organisms, like barnacles and brittle stars (Ohtsuka et al., 2010; Álvarez-Tello et al., 2013; Yusa et al., 2015).

While research has expanded around services jellyfish provide (Riascos et al., 2018), much of this research focuses on benefit and harm to vertebrates (Brodeur, 1998; Cardona et al., 2012; Mir-Arguimbau, Sabatés \& Tilves, 2019). However, the relationships between scyphomedusae, hydromedusae and other invertebrates are currently poorly characterized. A prime invertebrate group to analyze through this lens is Crustacea. Crustaceans are some of the most visible and well-studied marine invertebrates. They are present in every region and are integral components of food webs, including species of high commercial value and known ecological significance (Boudreau \& Worm, 2012). Ecological processes that impact them are thus relevant to humans. However, studies focusing on epifaunal crustaceans and jellyfish interactions have been scarce, incomplete, and taxonomically imprecise. Moreover, such studies are often narrowly focused accounts of interactions with single individuals (Weymouth, 1910; Reddiah, 1968; Yusa et al., 2015). Some early communications discuss these interactions as 
59 common knowledge that has, however, failed to be recorded in the scientific literature

60 (Jachowski, 1963). This review provides a list of documented crustacean epibionts on medusae

61 of the orders Scyphozoa and Hydrozoa. This work aims to assess the breadth and depth of

62 jellyfish-crustacean interaction and develop a resource for further studies.

\section{Methodology}

Four independent sets of searches were conducted in Google Scholar using keywords, as described in Fig. 1. All four searches were conducted in early November 2019 and were revisited in January 2021 to include all results through the end of 2019. Searches were performed in English, and as such, only papers published in or with an available translation to English were included. The number of papers yielded by each of the four searches is shown in Fig. 1, ranges from 4,840 articles (for keywords Crustacea, Scyphozoa) to 13,300 (for keywords Crustacea, Jellyfish) (See Fig. 1 for details). Only papers in which the primary focus was associations between medusae (Hydrozoa and Scyphozoa) and crustaceans were further selected.

The four searches performed returned many invariable results. All titles and abstracts were checked for relevance. Results from 161 papers were obtained initially and then narrowed to 81 , after excluding repeat papers mistakenly included multiple times and papers on cubomedusae, ctenophores, ascidians, and non-crustacean epibionts. Also, results from six relevant literature reviews were included (Vader, 1972; Pagès, 2000; Towanda \& Thuesen, 2006; Ohtsuka et al., 2011; Schiariti et al., 2012; Wakabayashi et al., 2019). These reviews account for 40 interactions from 29 sources (Table 1). The inclusion of the literature reviews was deemed essential to include results from earlier sources and non-English sources not available on Google Scholar. Results from literature reviews that had no information on the nature of the interaction between the medusa and crustaceans (such as taxa identification, location, etc.) were eliminated. 
82 Records were also analyzed for taxon validity using the World Register of Marine Species

83 (WoRMS). Seven papers within the database that referred to invalid taxa with no valid

84 synonymized name in WoRMS were removed. Results from 97 unique sources (68 articles from

85 the Google Scholar search and 29 from literature reviews) were kept. From these 97 sources, 211

86 distinct interactions were extracted. Details provided by each paper were recorded in Table 1.

\section{Results and Discussion} between hydrozoan or scyphozoan medusae and crustaceans, extracted from 97 papers (Table 1). For both cnidarians and crustaceans, order, family, genus, and species are included in Supplementary Materials. Results that lacked taxonomic identification (at least Family level) were not included. The final table (Table 1) provides sampling information, such as year and month of sampling, sampling method, and region of sampling. For crustaceans, records include the life stage involved in the interaction, sex of the epibiont, location on the hosts, and additional notes, if available. In most studies, fewer data were available on the cnidarian hosts, reducing the degree to which these interactions could be analyzed in terms of hydromedusan or scyphomedusan life stage. In the next paragraphs, we discuss the jellyfish-crustacea interactions through all of the categories included.

\section{DIVERSITY}

A supermajority of records (70\%, or 148/211) involves Scyphomedusae, with 53 records involving just the five most common scyphozoan species: Lychnorhiza lucerna (Haeckel, 1880),

103 Catostylus mosaicus (Quoy \& Gaimard, 1824), Stomolophus meleagris (Agassiz, 1860), Cyanea 
104 capillata (Linnaeus, 1758) and Rhopilema hispidum (Vanhöffen, 1888). These records are 105 heavily concentrated in the upper water column. Deeper water collections (ROV/HOV) were 106 dominated by hydromedusae (69\%, or $27 / 39)$, while records involving the upper water column

$107(0-30 \mathrm{~m})$ were more common and dominated by scyphomedusae (78\%, or $83 / 106)$. Sixty-seven 108 records included no specific sampling depth. These records were generally more than 50 years 109 old. Although they are likely near-surface sampling records and mainly report known shallow110 water species, they cannot be verified as such because of the lack of explicit information. Most

111 of these (87\%, or 58/67) are records of scyphomedusae. Overall, the diversity of scyphomedusae 112 was low, with only 39 species from 27 genera represented in records (Fig 2a). The genus

113 Chrysaora had the largest contingent of accounts, with 21 individual records of associations

114 across at least seven Chrysaora species. This genus has been reported to interact with 16 115 different epifaunal crustaceans. The genera Chrysaora, Lychnorhiza, and Catostylus accounted

116 for a third of scyphozoan records. These records originate mainly from the upper water levels of 117 various locations (i.e., the east coast of the United States, the southeast of Brazil, the southern 118 Australian coast, and the western Philippines, Japan and Pakistan). Diversity of hydrozoan hosts

120 Twenty-six genera, and six Hydrozoan orders were reported interacting with Crustacea in 63 121 records (Fig $2 b$ ). The order Leptothecata included the greatest number of records (18), with 17 122 records of Siphonophorae and 12 of Narcomedusae. The diversity of Hydrozoa was significantly 123 limited by region, with 45 of the 63 records (71\%) from the Gulf of California. Additionally, 124 those from the Gulf were acquired from primarily deep water ROV missions. The medusae 125 recorded belonged to 28 known species, with twelve records unable to provide higher resolution 126 than genus and a single Prayid siphonophore only identified to the family level. Rosecea 
127 cymbiformis (Delle Chiaje, 1830) (4), Aegina citrea (Eschscholtz, 1829) (5), and Aequorea

128 coerulescens (Brandt, 1835) (6) were the three most common species.

The crustaceans included Hexanauplia (reported in 37 discrete observations),

Malacostraca (173), and a single representative of Branchiopoda (Evadne sp.) (Fig. 3). Recorded overall low species resolution, with 13 of the 23 documented associations lacking a species name. The Macrochironidae, a group of known scyphozoan parasites, makes up 12 of the copepod epibiont records. Outside of this family, no additional Hexanauplia epibiont was recorded more than twice. The single reported case of a medusa with Evadne sp. occurred in a broad analysis of items found on a Catostylus medusae (Browne \& Kingsford, 2005). As this was not replicated throughout medusae within the study, or in other studies, it is unlikely this is a common or genuine association. records include amphipods and decapods in equal proportion (47\%, or 81/173 each), isopods

$142(5 \%$, or $9 / 173)$, and mysids $(1 \%$, or $2 / 173)$. The amphipods are dominated by the parasitic family Hyperidae, recorded in 32 separate encounters. Members of the family of Hyperidae are present across 22 identified scyphozoan and hydrozoan species, making them the most widely distributed family. Hyperia galba (Montagu, 1813) is present in nine records from both surface and deep-water samples, making it the single most plentiful within the amphipods. Outside of the

147 family Hyperidae, Tryphana malmii (Boeck, 1871) is recorded six times in association with deep-sea jellyfish. Most amphipod species recorded were recorded on multiple host species. 
Portunidae (14), Palaemonidae (12), Hippolytidae (14), Scyllaridae (11) Cancridae (6),

Grapsoidea (1). No decapod was found in association with hydrozoans or in deep-sea records.

The representatives of Epialtidae are comprised exclusively of multiple species of the genus

Libinia. The Portunidae records are mainly composed of the commercially valuable Charybdis

feriata (Linnaeus, 1758) (11 records), Charybdis annulata (Fabricius, 1798) (1) and two

Callinectes, Calinectes sapidus (Rathbun, 1896) and an unidentified Callinectes specimen (1).

Periclimenes paivai (Chace, 1969) is the most common Palaemonidae, representing three of the

twelve records, with six additional Periclimenes species, two Ancylomenes species and one

Leander paulensis (Ortmann, 1897). All Hippolytidae associations were between a specimen of array of different scyphomedusae in Asia, Australia, and the Arabian Sea-Persian Gulf corridor.

The families Scyllaridae and Scyllarinae include seven Ibacus, three Scyllarus, and Eduarctus martensii (Pfeffer, 1881). These associations were all exclusively larval. The majority (4) of Cancridae records involve Metacarcinus gracilis (Dana, 1952) with two unknown Cancer species. These crabs were found on Chrysaora medusae and one Phacellophora camtschatica (Brandt, 1835). Two Chlorotocella gracilis (Balss, 1914) (Chlorotocellidae) were found on Japanese rhizostomes, both in somewhat limited encounters. The last three accounts include a Cyrtograpsus affinis (Dana, 1851) (Family: Varunidae), Lucifer sp. (Family: Luciferidae), and a juvenile Grapsoidea of unknown genus and species. The account of Lucifer sp. was of a record of one specimen on a medusa in New South Wales, and is not likely a common or genuine association (Browne \& Kingsford, 2005). Cyrtograpsus affinis and the juvenile of the family 
172 Grapsoidea were also one-off reports found in single medusae (Schiariti et al. 2012; Gonçalves et 173 al. 2016).

Associations that involved mysids or isopods were far fewer than those involving decapods and amphipods. The isopod records include only four species, including the deep-sea parasite Anuropus associated with Deepstaria enigmatica (Russell, 1967). Besides the in situ accounts of the Deepstaria scyphomedusae with an attached Anuropus, three Isopoda species were found in association with upper water column medusae. These are Cymodoce gaimardii (H. Milne Edwards, 1840) and Synidotea marplatensis (Giambiagi, 1922), each recorded three times, and Cymothoa catarinensis (Thatcher et al., 2003), found once in association with Chrysaora lactea (Eschscholtz, 1829). Within the order Mysida, the two species Mysidopsis cathengelae (Gleye, 1982) and Metamysidopsis elongata (Holmes, 1900) were recorded on Chrysaora during a bloom in the Southern California Bight (Martin \& Kuck, 1991). pacifica (Pilsbry, 1907) accounting for twelve of such records, Conchoderma virgatum

186 (Spengler, 1789) accounting for two, and a single report of an unidentified Anelasma epibiont on a Pelagia noctiluca (Forsskål, 1775) from 1902. Alepas pacifica has been found on seven separate host species, all scyphozoans. The vast majority of these records came from a single literature review included within an extensive paper from Vader (1972). None of these species were found in deep-sea records.

\section{FIELD COLLECTIONS}

(Fig 4). Between 1862 and 1962, only seven of the twenty records reported a method of capture. 
194 From 1963 to 1989, this increased to 64\%, with 25 of 39 records including the collection

195 method. Since 1990, there have been only seven failures to report collection methods out of 140

196 accounts. The most common method of collection, used in 31 of the papers, is "by hand", defined

197 as using handheld dip nets, buckets, plastic bags, and, in limited cases, collection of carcasses

198 from beaches. Trawling was first used in 1968 and has remained in use until recently, reported in

19917 of the 33 associations after 2010. Although 38 records were obtained through deep water

200 methods (HOV and ROV), these were used scarcely before 1999. Some studies employed

201 multiple methods, with divers and ROV, or dip net and trawl capture, such that it was unclear

202 which associations were found by each collection method. These were listed as "multi-method"

203 and include four papers.

The larger proportion of scyphozoan hosts to hydrozoan hosts may be a sampling artifact.

The vast majority of the papers discussed here were only analyzing interactions in the top $30 \mathrm{~m}$

of the water column. A fair number, especially earlier texts, involve serendipitous encounters at

the water's edge or within sight of the surface (Bowman, 1963; Jachowski, 1963; Vader, 1972;

Martin \& Kuck, 1991). The larger, more visible nature of surface water scyphozoans of the

rhizostomes and semaeostomes makes them an easier collection target than deep water species.

Note that only a single scyphozoan of the order Coronatae, which has no large shallow

representatives, was recorded as well. Many elements of the sampling methods impact the scope of this data, and the preeminence of hand collection and papers written on chance occurrences, as opposed to prolonged study, result in a picture that heavily weights organisms more frequently seen or interacted with by humans. 
217 associations from the Chesapeake Bay (Bowman 1963). Buckets and nets have remained

218 mainstays, with hand collection accounting for 34 of the 108 post-2000 records and 32 of the 55

219 pre-2000 records. Buckets and plastic bags are likely preferable to nets, as they may reduce

220 chances of epibiont detachment and medusa damage.

Trawling (by ring nets, otter nets, and bottom trawls), while reported in twelve papers,

222 has been a prominent capture method in South America for the last two decades. However,

223

224

225

226

227

228

229

230

231

232

233

234

235

236

237

238

239 trawling provides an additional threat, as epibionts may detach, get caught in the bell of a medusa, or move to a different location within the carcass. Given the damage sustained by gelatinous bodies during trawls, and the inability to capture more delicate associations, this is the methodology that seems most likely to provide low-quality relationship information. A focus on a lower number of medusae examined in more detail, may provide more useful information on the ecology of the interaction between jellyfish and their epibionts. Notably, Greer et al. (2017) uses a combination of in situ imaging (with an automatic ISIIS imaging system) and trawls. Trawls were used to verify the identity of organisms seen in the captured images. Such a protocol should be considered for future quantitative and qualitative work. $66 \%$ of the records $(136 / 211)$ are from known surface encounters. $18 \%$ of the records (38/211) involve deep water accounts using either an ROV/HOV. These records are distributed unevenly across depths with few records below the mesopelagic zone (Fig 5). Most of these records fail to provide epibiont location on the jellyfish but provide the only available information on deep water scyphomedusa and hydromedusa hosts. Most of the deep water records are from the Gulf of California. While this sampling method is useful, the high cost and difficulty of use of ROV and HOV equipment make it unrealistic for the vast majority of researchers. The limited number of deep-water accounts and the novelty of many of the findings

Peer] reviewing PDF | (2020:12:56424:2:0:NEW 10 Mar 2021) 
240 on each dive can be attributed mainly to these limitations (Gasca and Haddock, 2004; Gasca et

241 al., 2007; Gasca et al., 2015).

242 Given the fragility of scyphozoan and hydrozoan medusae, as well as the delicacy of the

243 interaction with their epibionts, the most precise picture of the jellyfish-crustacean associations

244 has been achieved from dip net, plastic bag, bucket, or other by-hand collection methods. These

245 are not only a cost-effective strategy requiring little additional equipment, they also maintain

246 maximum integrity of the organisms. Hand collection, however, is restricted to analyzing

247 associations that are close to the surface. Trawl sampling provides a reliable way to collect many

248 medusae offshore but sacrifices sample integrity. ROV is an imperfect sampling method, often

249 failing to record epibiont positioning, but allows for the only viewing, documentation, and

250 collection of deep water associations, thereby being uniquely important, especially for

251 hydromedusa research. Moreover, the majority of the records document all symbionts on the

252 target host species, often with little data beyond a name or tentative classification for the

253 epibiont. This lack of closer examination leads to an inability to correctly categorize the nature of

254 the relationship, including positioning, feeding behaviors, and duration of the interaction.

In conclusion, the overall best sampling results come from observation-first

256

257

258

259

260

261

262 methodologies such as collection by-hand while snorkeling and diving, as in Mazda et al. (2019), ROV/HOV in situ underwater photography, as employed by Gasca et al. (2015), or imaging and supplemental trawling as in Greer et al. (2017). Obtaining underwater pictures of medusae and epibiont is crucial to the understanding of the associate placement in relation to host and its behavior. It is also more informative than post hoc in-lab examinations and analysis of trawl contents, because the stress of collection and sampling may impact the epibiont position within the host (Hayashi et al. 2004). As waterproof video equipment becomes less expensive, options 
263 like a simple GoPro may provide clear enough imaging to allow novel in situ observations.

264 Adding an underwater imaging component to sampling may also enable collectors to revisit the 265 ecological context of the association.

\section{LIFE STAGES}

Age classes and sex, where available, are reported in Table $1.63 \%$ of all records

268

269

270

271

272

273

274

275

276

277

278

279

280

281

282

283

284

285

$(133 / 211)$ reported an age class for the crustacean. $65 \%$ of the interactions with a listed age class (65\%, or $86 / 133)$ reported crustacean juveniles, eggs, larval stages, copepodites, megalopae, or other immature forms. For a minority of records $(37 \%$, or $73 / 211)$, no information on the crustaceans' age class and sex was available. When individuals were described as "male" or "female" without any qualifier attached, they were catalogued and treated as adult specimens (Table 1). Megalopae were noted only nine times out of the 106 records that reported an age class for the crustacean associate ( $8 \%)$. In these nine records, the megalopae belonged to the genera Callinectes, Periclimenes, Metacarcinus, Cancer, and Charybdis, and were all in association with Scyphomedusae (Orders: Rhizostomeae and Semaeostomeae). In addition to megalopae, phyllosoma larvae of the families Scyllaridae and Scyllarinae were reported 12 times. The occurrence of larvae of this type associated with medusae and, more generally, with gelatinous zooplankton is well known, especially along the Japanese coast (Wakabayashi et al., 2019). Within and upon the host, juvenile crustaceans were often coexisting with adult forms. Eighty-one of the associations include juveniles (excluding megalopae, eggs, and copepodites), sometimes embedded in host tissue (Theusen, 2006; Browne, 2015; Towanda \& Yusa et al., 2015; Browne et al., 2017; Mazda et al., 2019). The presence of eggs and ovigerous females was reported in 39 cases from 23 different species. In at least three papers, females and ovigerous females were present in exceptionally high proportions relative to adult males (Martinelli-Filho 
286 et al., 2008; Oliva et al., 2010; Mazda et al., 2019). Records of megalopae of the commercial

287 crab, Charybdis feriata were reported in substantial numbers on two separate hosts (Kondo et al.,

288 2014; Boco \& Metillo, 2018). In other reports, associations between juvenile Metacarcinus

289 gracilis (Dana, 1852) and medusae are hypothesized to be beneficial to the crab as the medusae

290 supply means of transport and food acquisition, which may be similar across juvenile decapod-

291 scyphozoan associations (Towanda \& Thuesen, 2006).

292

293

294

295

296

297

298

299

300

301

302

303

304

305

306

307

308

\section{NATURE OF ASSOCIATIONS BETWEEN MEDUSAE AND CRUSTACEANS}

There is no agreement between authors on the degree to which medusae and crustaceans' interactions are parasitic, commensal, or otherwise. In the case of the scyphozoan Phacellophora camtschatica and the decapod Metacarcinus gracilis (Dana, 1852), the interaction may involve a mutualistic cleaning relationship as $M$. gracilis graduates into adulthood (Towanda \& Thuesen, 2006). Other reports of megolopae do not suggest any parasitization of the medusae. Weymouth (1910) also indicates that this is a commensal relationship important to M. gracilis megalopae until they reach $\sim 20 \mathrm{~mm}$. In other cases, such as the shrimp Perimincles paivai, the commensals seemed to be feeding on the mucus, not the host tissue (Browne \& Kingsford, 2005; MartinelliFilho et al., 2008). Dittrich (1988) demonstrates an aggressive parasitoidism by Hyperia galba in which a large subset of host medusae was so reduced by predation as to lose almost all morphological features. While the ultimate death of these hosts is not recorded within the text, the loss of all tentacular structure and non-mesoglear tissue would make survival nearly impossible. The numbers in which Hyperia can be found on some of the recorded medusae, occasionally upwards of 100 amphipods engaging in host consumption, may lend credence to the parasitoid rather than classically parasitic nature of this relationship in many hosts (Vader, 1972;

Dittrich, 1988; Towanda \& Thuesen, 2006). However, additional reports on the same species and 
309

310

311

312

313

314

315

316

317

318

319

320

321

322

323

324

325

326

327

328

329

330

331

other hyperiids reported that this group engages in cradle positioning, facing outwards from the medusa, into the water column with no reported predation, or engage in only limited predation of the gonadal tissue or mesogleal tissue (Bowman et al., 1963; Gasca et al., 2005; Browne, 2015). Based on this information it seems likely that the family Hyperidae includes a variety of strategies, and the family Hyperia itself may also encompass non-aggressive parasitism, aggressive parasitism, and parasitoidism. In part, this may be due to temporal behavioral differences within species, with more extreme predation in summer and autumn and limited parasitism in spring as populations raise and fall (Bowman, 1963; Dittrich, 1988). "Inverted cradle" positioning is a recurring feature of amphipod associates (Bowman et al., 1963; Condon $\&$ Norman, 1999). While some of the crustaceans fed on the medusae themselves, Towanda and Thuesen (2006) primarily recorded crustaceans engaging in theft of prey collected by medusae. Many crustaceans that were reported feeding on the medusae were feeding entirely or in part on the highly regenerative gonadal tissue (Pagès, 2000; Towanda \& Thuesen, 2006; Ohtsuka et al., 2009) or engaging in the excavation of small pits in the host mesoglea (Humes, 1953; Jachowski, 1963; Browne, 2015). Reports of Libinia dubia (H. Milne Edwards, 1834) have the greatest agreement on the parasitic nature of the species' interactions with their medusa host (Jachowski, 1963; Phillips et al., 1969; Schiariti et al., 2012).

The largest exception to the above patterns of limited consumption or longer term residence is the scholarship surrounding phyllosoma larvae on gelatinous zooplankton. These larvae have been reported to stab a pair of pereiopods through the exumbrella or exterior of a nectophore and use the medusa as propulsion and food source. This is a common occurrence both in the northern Gulf of Mexico and at various locations along the Japanese coast (Greer et al., 2017; Wakabayashi et al., 2019). In the review on the subject by Wakabayashi et al. (2019), 
332 it is hypothesized that the flattened body and ventral mouth of these phyllosoma larvae is ideal

333 for consumption of gelatinous zooplankton while attached. The exact length of this parasitoid

334 association is unknown, though it is likely generally ended by the medusa's eventual death as the

335 larva eats its way through.

The degree to which crustaceans engage in host consumption may be in part obscured by

337 the speed with which medusae regenerate tissues, especially gonadal and oral arm tissues

338 (Towanda \& Thuesen, 2006). The number of associates (at least eight crustacean species) found

339 residing within the bell and around the gonads, suggests that gonadal tissue may be common

340 nourishment even when bell and arm tissue is not consumed. Overall, the relationships of

341 crustaceans with their medusa hosts remain largely uncharacterized and require additional study.

342 Few papers have analyzed the gut contents of the epibionts, which would be a helpful tool in

343 determining whether inverted positioning on hosts was actually a signal of lack of consumption,

344 or simply a break from such (Vader, 1972; Pagès, 2000; Towanda \& Thuesen, 2006; Oliva et al.,

345 2010; ). Detailed records of the diets of such organisms are difficult to reconstruct. However,

346 specific searches for nematocysts in digestive tract and excretions or stable isotope analysis have

347 proven successful at identifying cnidomedusae as possible food sources (Schiariti et al., 2012;

348 Fleming et al., 2014). Expanding future works to include both these practices, photographs of the

349 host medusae, and notes on swimming strength, tentacular loss and other signs of deterioration

350 would improve our understanding of how detrimental these relationships actually are. This sort

351 of documentation of host condition is impossible when specimens are collected via trawl.

354 host symbionts, others in the same area lack them due to their size or species (Towanda \& 
355 Theusen, 2006; Ohtsuka et al., 2011; Boco and Metillo, 2018). While exotic species often have

356 lower amounts of parasitization in their introduced range (Torchin et al., 2003), the degree to

357 which epibionts in medusae are affected by host or epibiont endemicity is unknown. The high

358 number of cryptic species, a history of misidentification, and poor understandings of historical

359 ranges compound issues with sparse research on the topic (Dawson, 2005; Graham \& Bayha,

360 2008; Morandini et al., 2017; De Souza \& Dawson, 2018). gelatinous zooplankton hosts and epibionts may be; six years of monthly observation showed that single adult females of the amphipod Oxycephallus clausi (Bovallius, 1887) had a broad range of gelatinous hosts, but shifted to primarily Ocyropsis fusca (Rang, 1827), a lobate ctenophore, during brood release (Mazda et al., 2019). While ctenophores are not the focus of this review, it shows that the nature of interactions may change during the crustacean lifecycle. These sorts of long-term analyses are hard to pursue, but provide a fascinating look at the range of information that can be collected with observational methods. Uneven sex ratios, such as those seen in the case of Oxycephallusclausi ( $97 \%$ female), are present across many associations (Condon \& Norman, 1999; Martinelli-Filho et al. 2005; Oliva et al., 2010; Mazda et al., 2019).

The most common explanation for this higher ratio of females and often ovigerous females is use of scyphozoan and hydrozoan hosts primarily as nursery habitat for movement and protection of

373 juveniles (Gonçalves et al., 2016; Gonçalves et al., 2017; Mazda et al., 2019). Potential

374 territoriality in some females, like those of $P$. paivai, may help ensure more resources for their

375 brood, and is in line with other symbiont crustaceans (Baeza et al., 2017). For deep sea 376 crustaceans, such as Pseudolubbockia dilatata (Sars, 1909), more even sex ratios would be 377 expected, as there is evidence of long-term resident brooding pairs, and mate scarcity is a feature 
378 of deep sea life. Evidence for long-term association and pairing has not been found for other

379 deep water crustaceans, although understanding these deep sea interactions is generally

380 hampered but small sample sizes and difficulty of observation (Gasca et a., 2007; Baeza et al.,

381 2017; Gasca et al., 2018).

382

383

384

385

386

387

388

389

390

391

392

393

394

395

396

397

398

399

400

\section{YEARS AND LOCATIONS}

The oldest records examined were only available from earlier literature reviews (Pagès, 2000; Towanda \& Thuesen, 2006; Schiariti et al., 2012). The first record is the Bate (1857) account of the amphipod Iphimedia eblanae on the scyphozoan Rhizostoma pulmo (Macri, 1778) from 1862, also reported in the Vader (1972) review on amphipod associations with medusae. Thiel (1976) refers to older records from as far back as 1791. Overall, the number of records detailing interactions has risen over time but has not exceeded ten papers during any five years. While these numbers are increasing modestly, the number of distinct interactions that any given paper reports have increased. Pre-1990s articles, on average put forward information on 1.24 associations per paper. In contrast, the average number of associations reported in papers published from 1990 to 2018 increased more than twofold (an average of 2.83 records per paper). These surveys provide useful records of separate associations found in one area or on one organism and are informative of ecosystem features on a regional level. Still, given the studies' breadth, they often lack depth, not characterizing relationships between individual host species and their associates.

Records were unevenly distributed globally, with Africa and Europe completely devoid of records from the past thirty years with the exception of a single note on an accidental observation from Gran Canaria, Spain. The eastern coast of North America (one record since 1984 (Tunberg \& Reed, 2004) and China (no direct records), as well as West Africa (one record 
401 from 1972 (Bruce, 1972)) and the Mediterranean Sea (last collections 1985 (Dittrich, 1988) also

402 lack records from the last 30 years. The areas consistently covered by recent papers are Australia 403 (1968-2009), the Philippines (2014, 2018), the eastern coast of South America (1980-2016), and 404 the western United States (1966-2015). Japanese records represent the longest continuity over 405 time, with 33 records between 1902 and 2019. The association that consistently appears 406 throughout time is that of Alepas pacifica (Thoracica, Lepadiformes) with Nomura's Jellyfish 407 (Nemopilema nomurai) (Pagès, 2000; Yusa et al., 2015). The first record of this association was 408 in 1902 (Pagès, 2000), and the most recent in 2015 (Yusa et al., 2015). Phyllosoma larvae of 409 multiple species, Chlorotocella gracilis (Balss, 1914), and Latreutes spp. also have records 410 spanning multiple decades and papers.

411 It is worth mentioning that the uneven geographic distribution of associations reported 412 herein may be an artifact of lack of readily available English translations of works from some 413 areas. Reports from Japan and China of crustacean and gelatinous zooplankton associations are 414 mentioned by Hayashi et al. (2004) and Wakabayashi et al. (2019), but were not available in 415 English and therefore are not accounted for in this review. Similarly, European records may be underestimated, as non-English records are absent. Other locations' lack of records may be a

417 more accurate representation of a gap in academic knowledge. Africa's west and eastern coasts 418 are known to be understudied ecosystems, and so the missing research here is likely not just 419 untranslated (Berkström et al., 2019). As in other ecological inquiries, the expansion of Local

420 Ecological Knowledge into the study of gelatinous zooplankton should be considered, as 421 fishermen and coastal communities often have a deep knowledge of organisms and their 422 associations (Berkström et al., 2019). Fishermen are often well acquainted with specific 
423 gelatinous zooplankton species and know their harms, and may have knowledge of symbionts

424 living upon or within them (Al-Rubiay et al., 2009).

425 COMMERCIAL SPECIES

Many commercial crustaceans and jellyfish were found to have associations that may be

427 of ecological and commercial importance. Twelve records reported the edible jellyfish

Rhopilema spp. as hosts (Berggren, 1994; Pagès, 2000; Hayashi et al., 2004; Towanda \&

Theusen, 2006; Ohtsuka et al., 2010; Ohtsuka et al., 2012; Boco \& Metillo, 2018). The

commercially harvested shrimp, Penaeus stylirostris (Stimpson, 1871), was found on

Stomolophus meleangris (Riascos et al., 2018). Notably, young Callinectes sapidus, the

432

433

434

435

436

437

438

439

440

441

442

443

444
Chesapeake Blue Crab, was reported by Jachowski (1963) as regularly found on Chrysaora quinquecirrha (Desor, 1848) medusae without consuming them. This association was reported again briefly in the Mississippi Sound by Phillips et al. (1969). This interaction between a jellyfish and the blue crab has never been corroborated further except for a nonspecific report of a Callinectes sp. associated with jellyfish reported by Towanda et al. (2006) as unpublished data. The commercially valuable crab, Charybdis feriata, has been reported in association with ten jellyfish species (Berggren, 1994; Towanda \& Thuesen, 2006; Ohtsuka et al., 2010; Schiariti et al., 2012; Boco et al., 2014; Boco \& Metillo, 2018). These reports involve juveniles (Trott, 1972; Towanda \& Thuesen, 2006; Schiariti et al., 2012; Kondo et al., 2014; Boco \& Metillo, 2018) and megalopae (Kondo et al., 2014; Boco \& Metillo, 2018) of C. feriata, and this association has been recorded in Hong Kong, Japan, the Philippines, Mozambique, and Indonesia, suggesting a consistent pattern over time (first record in 1965 (Schiariti et al., 2012) and last record in 2014 (Boco \& Metillo, 2018)) and across their range.

Peer] reviewing PDF | (2020:12:56424:2:0:NEW 10 Mar 2021) 

across various hosts (Wakabayashi et al., 2019). Some slipper lobsters are commercially fished

447 for consumption, and a large number of these larvae ( $40 \%$ in the Gulf of Mexico) have been

448 shown to live attached to gelatinous zooplankton (Greer et al. 2017).

The consumption of some Scyphozoan hosts, such as Catostylus mosaicus and Rhopilema spp., makes their records valuable as well. The fishing pressures on the jellyfish populations may significantly impact the crustaceans that rely on their oral arms and bells for transport and nourishment of their juvenile stages. Further understanding of these relationships may be especially important in cases where both the medusae (e.g., Rhopilema spp., Lobonemoides robustus (Stiasny, 1920) and Catostylus spp.) and crustacean (Charybdis feriata) are subject to fishing (Boco et al., 2014; Boco \& Metillo, 2018, Kondo et al., 2014). Finally, current information on Callinectes sapidus and its relationship to and frequency of interaction with host

457 jellyfish is needed, as the blue crab represents a commercially valuable fishery in the Gulf of 458 Mexico and along the Atlantic Coast of the USA. Crustacea and common scyphozoans and hydrozoans can improve fisheries practices and regulation, as already acknowledged for economically important fish and their jellyfish hosts (Tilves et al., 2018). The importance of maintaining juvenile communities for commercially sized adult populations to recruit from is well established and a frequent impetus for marine protection areas. The fishing of medusae is different from most modern vertebrate fishing. It is temporally highly variable, and blooms, when found, are fished as intensely as possible by local 
468 jellyfish species known to harbor juveniles of commercially viable crustaceans. It is clear that

469 many crustaceans, fish, and other organisms live in, upon and around medusae, thus

470 indiscriminate efforts to remove or destroy blooms of endemic species are likely unwise (Tilves

471 et al., 2018; Riascos et al., 2018).

\section{Conclusion}

473

474

475

476

477

478

479

480

481

482

483

484

485

486

487

488

489

490

Many of the interactions we reviewed are fragmented and not comprehensive. Studies covering timing and breadth of infection of commercially valuable crustaceans on marine scyphozoans are scarce, but may be valuable information to fully understand the complexity of their life cycle, and thus the species' vulnerability at each life cycle stage. The general picture of the commensal relationships that arise from this review is complex and emphasizes the diversity of jellyfish and crustaceans' relationships. Any attempt to paint them as uniformly parasitic fails to acknowledge the diversity of crustacean host-use strategies. While some seem to be parasitic or parasitoid, others are life-stage dependent commensals reliant on medusae for transportation. Some deep water crustaceans may be lifelong commensals (Gasca et al., 2007). In each of these cases, the work thus far is far from exhaustive. Additional research on seasonality, maternal care, territoriality, impact on host and other such matters should be further pursued.

The scyphozoans and hydrozoans studied here represent only a small proportion of the globally recognized species. Even shallow water coastal species are poorly covered. This research has been restricted to a small selection of near-shore sites over the past 50 years, leaving inadequate coverage even in regions with a significant scyphozoan research presence (i.e., the Mediterranean, western Europe, China, northeastern North America). Because much of the published research focused on single occurrences, this paper's overall results do not necessarily capture the broader ecology of the species involved (Bowman, 1963; Jachowski, 1963; Suzuki, 
491 1965; Ohtsuka et al., 2011). Similarly, species descriptions that mention an association without

492 details on the conditions in which it was found offer little insight on the frequency and ecological

493 role of such interactions (Humes, 1953; Reddiah, 1968; Bruce, 1972; Criales, 1984; Bruce, 1988;

494 Bruce, 1995; Bruce, 2005).

495

Best practices moving forward should include some of the following elements: in situ

496

imaging pre-collection, observations on medusa health, analysis of epibiont gut contents when

497

possible, preferential use of non-destructive collection methods, observations on symbiont

498

placement within or upon the medusa, and frequency, geographical and temporal variation of the

499

association.

500

With this review, we hope to highlight a significant knowledge gap and a lack of formal

501

study on the ecology of the crustaceans residing on and around jellyfish, as well as a glimpse of

502 the ecological complexity of these interactions. We provide easy access to a century of

503 ecological research and a framework for analyzing and contextualizing future research on this

504 topic.

505

\section{References}

506

Al-Rubiay KK, Al-Musaoi HA, Alrubaiy L, Al-Freje, MJ. 2009. Skin and systemic

507

manifestations of jellyfish stings in Iraqi fishermen. Libyan Journal of Medicine, 4:2. DOI:

$508 \underline{10.4176 / 081215}$.

509 Álvarez-Tello FJ, López-Martínez J, Rodríguez-Romero J. 2013. First record of the association 510 between Stomolophus meleagris (Cnidaria: Scyphozoa : Rhizostomeae) and Conchoderma $\mathrm{cf}$

511 virgatum (Crustacea: Cirripedia: Thoracica) in the Gulf of California. Hidrobiológica 23:138-

512142.

513 Annandale N. 1914. New and interesting pedunculate cirripedes from Indian Seas. Records of the 514 Indian Museum 10:227-236.

515 Ates R, Lindsay DJ, Sekiguchi H. 2007. First record of an association between a phyllosoma 516 larva and a Prayid siphonophore. Plankton Benthos Res 2(1): 67-69.

517 Baeza JA, de Paiva Barros-Alves S, Lucena RA, Lima SFB, Alves DFR. 2017. Host-use pattern 
518 of the shrimp Periclimenes paivai on the scyphozoan jellyfish Lychnorhiza lucerna: probing for 519 territoriality and inferring its mating system. Helgoland Marine Research 71. DOI:

520 10.1186/s10152-017-0497-8.

521 Barham EG, Pickwell G V. 1969. The giant isopod, Anuropus: A scyphozoan symbiont. Deep-

522 Sea Research and Oceanographic Abstracts 16. DOI: 10.1016/0011-7471(69)90040-0.

523 Bate CS. 1862. Catalogue of the specimens of amphipodous Crustacea in the collection of the

524 British Museum by C. Spence Bate. London: Printed by order of the Trustees.Berggren M. 1994.

525 Periclimenes nomadophila and Tuleariocaris sarec, Two new species of Pontoniine shrimps,

526 from Inhaca Island, Mozambique. Journal of Crustacean Biology 14(4): 782-802.

527 Berkström C, Papadopoulos M, Jiddawi NS, and Nordlund LM. 2019. Fishers' local ecological 528 knowledge (LEK) on connectivity and seascape management. Frontiers in Marine Science 6:

529 130. DOI: 10.3389/fmars.2019.00130

530 Boco SR, Metillo EB. 2018. Observations on the specific associations found between

531 scyphomedusae and commensal fish and invertebrates in the Philippines. Symbiosis 75:69-79.

532 DOI: 10.1007/s13199-017-0513-4.

533 Boco SR, Metillo EB, Papa RDS. 2014. Abundance, size and symbionts of Catostylus sp.

534 Panguil Bay, Northern Mindanao, Philippines. Philippine Journal of Systematic Biology 8.

535 Boudreau SA, Worm B. 2012. Ecological role of large benthic decapods in marine ecosystems:

536 A review. Marine Ecology Progress Series 469:195-213. DOI: 10.3354/meps09862.

537 Bowman TE, Meyers CD, Hicks SD. 1963. Notes on associations between hyperiid amphipods 538 and medusae in Chesapeake and Narragansett Bays and the Niantic River. Chesapeake Science 539 4:141-146. DOI: 10.2307/1350747.

540 Brodeur RD. 1998. In situ observations of the association between juvenile fishes and 541 scyphomedusae in the Bering Sea. Marine Ecology Progress Series 163:11-20. DOI:

$54210.3354 /$ meps 163011.

543 Brodeur RD, Ruzicka JJ, Steele JH. 2011. Investigating alternate trophic pathways through 544 gelatinous zooplankton and planktivorous fishes in an upwelling ecosystem using end-to-end 545 models. Interdisciplinary Studies on Environmental Chemistry: Marine Environmental Modeling 546 and Analysis:57-63.

547 Browne JG. 2015. Parasites of Jellyfish in Eastern Australia. PhD Thesis, Griffith School of 548 Environment.

549 Browne JG, Kingsford MJ. 2005. A commensal relationship between the scyphozoan medusae 550 Catostylus mosaicus and the copepod Paramacrochiron maximum. Marine Biology 146:1157551 1168. DOI: 10.1007/s00227-004-1517-1.

552 Browne JG, Pitt KA, Norman MD. 2017. Temporal patterns of association between the jellyfish 553 Catostylus mosaicus and a sphaeromatid isopod and parasitic anemone. Marine and Freshwater 554 Research 68:1771-1777. DOI: 10.1071/MF16076.

555 Bruce AJ. 1972. An association between a Pontoniinid shrimp and a rhizostomatous

556 Scyphozoan. Crustaceana 23:300-302. DOI: 10.1163/156854072x00192. 
557 Bruce AJ. 1988. Periclimenes tonga sp. nov., a commensal shrimp associated with a scyphozoan 558 host from Tonga (Crustacea: Decapoda: Palaemonidae). Micronesica 21:23-32.

559 Bruce AJ. 1995. Latreutes anoplonyx Kemp, 1914 (Crustacea: Decapoda: Hippolytidae), A jelly560 fish Associate New to the Australian Fauna. The Beagle: Records of The Museums And Art 561 Galleries of The Northern Territory 12:61.

562 Bruce, A. J. 2008. Periclimenes aqabai sp. nov, a further species of the aesopius species group 563 (Caridea: Pontoniinae) from the Red Sea. Zootaxa 1682: 27-32.

564 Cardona L, de Quevedo IÁ, Borrell A, Aguilar A. 2012. Massive consumption of gelatinous 565 plankton by mediterranean apex predators. PLOS ONE 7. DOI: 10.1371/journal.pone.0031329.

566 Chilton C. 1921. Fauna of the Chilka Lake. Amphipoda. Memoirs of the Indian Museum. 5:519567558.

568 Comeaux RS, Allison MA, Bianchi TS. 2012. Mangrove expansion in the Gulf of Mexico with 569 climate change: Implications for wetland health and resistance to rising sea levels. Estuarine, 570 Coastal and Shelf Science 96:81-95. DOI: 10.1016/j.ecss.2011.10.003.

571 Condon RH, Norman MD. 1999. Commensal associations between the hyperiid amphipod,

572 Themisto australis, and the scyphozoan jellyfish, Cyanea capillata. Marine and Freshwater 573 Behaviour and Physiology 32:261-267. DOI: 10.1080/10236249909379054.

574 Corrington JD. 1927. Commensal Association of a Spider Crab and a Medusa. Zoological 575 Laboratory of Syracuse University.

576 Criales MM. 1984. Shrimps associated with coelenterates, echinoderms, and molluscs in the 577 Santa Marta region, Colombia. Journal of Crustacean Biology 4(2): 307-317.

578 D'Ambra I, Graham WM, Carmichael RH, Hernandez FJ. 2014. Fish rely on scyphozoan hosts as 579 a primary food source: evidence from stable isotope analysis. Marine Biology 162:247-252.

580 DOI: $10.1007 / \mathrm{s} 00227-014-2569-5$.

581 Dawson MN. 2005. Cyanea capillata is not a cosmopolitan jellyfish: Morphological and 582 molecular evidence for C. annaskala and C. rosea (Scyphozoa: Semaeostomeae: Cyaneidae) in 583 South-eastern Australia. Invertebrate Systematics 19:361-370. DOI: 10.1071/IS03035.

584 De Souza MR, Dawson MN. 2018. Redescription of Mastigias papua (Scyphozoa, 585 Rhizostomeae) with designation of a neotype and recognition of two additional species. Zootaxa 586 4457:520-536. DOI: 10.11646/zootaxa.4457.4.2.

587 Dittrich B. 1988. Studies on the life cycle and reproduction of the parasitic amphipod Hyperia 588 galba in the North Sea. Helgoländer Meeresuntersuchungen 42:79-98. DOI:

589 10.1007/BF02364205.

590 Elmhirst R. 1925. Associations between the amphipod genus Metopa and coelenterates. Scottish 591 Naturalist 133 \& 134:149-150.

592 Fernando A, Ramamoorthi K. 1974. Rare occurrence of Conchoderma virgatum (Spengler, 593 1790)(Cirripedia-Lepadomorpha) on a scyphozoan medusa. Current Science India 43:126.

594 Martinelli-Filho JEM, Stampar SN, Morandini AC, Mossolin EC. 2008. Cleaner shrimp 
595 (Caridea: Palaemonidae) associated with scyphozoan jellyfish. Vie et Milieu 58:133-140.

596 Fleming NEC, Harrod C, Griffin DC, Newton J, Houghton JDR. 2014. Scyphozoan jellyfish

597 provide short-term reproductive habitat for hyperiid amphipods in a temperate near-shore

598 environment. Marine Ecology Progress Series 510:229-240. DOI: 10.3354/meps 10896.

599 Gasca AR. 2013. The male of the deep-living hyperiid Hyperoche shihi Gasca, 2005 (Peracarida:

600 Amphipoda) and a new symbiotic association in the gulf of california. Crustaceana 86:1539-

6011549.

602 Gasca R, Browne WE. 2018. Symbiotic associations of crustaceans and a pycnogonid with 603 gelatinous zooplankton in the Gulf of California. Marine Biodiversity 48:1767-1775. DOI: 604 10.1007/s12526-017-0668-5.

605 Gasca R, Haddock SHD. 2004. Associations between gelatinous zooplankton and hyperiid 606 amphipods (Crustacea: Peracarida) in the Gulf of California. Hydrobiologia 530-531:529-535. 607 DOI: 10.1007/s10750-004-2657-5.

608 Gasca R, Hoover R, Haddock SHD. 2015. New symbiotic associations of hyperiid amphipods 609 (Peracarida) with gelatinous zooplankton in deep waters off California. Journal of the Marine 610 Biological Association of the United Kingdom 95:503-511. DOI: 10.1017/S0025315414001416.

611 Gasca R, Suárez-Morales E, Haddock SHD. 2007. Symbiotic associations between crustaceans 612 and gelatinous zooplankton in deep and surface waters off California. Marine Biology 151:233613 242. DOI: 10.1007/s00227-006-0478-y.

614 Gómez Daglio L, Dawson MN. 2017. Species richness of jellyfishes (Scyphozoa:

615 Discomedusae) in the Tropical Eastern Pacific: Missed taxa, molecules, and morphology match 616 in a biodiversity hotspot. Invertebrate Systematics 31:635-663. DOI: 10.1071/IS16055.

617 Gonçalves GRL, Grabowski RC, Bochini, GL, da Costa RC, Castilho AL. 2017. Ecology of the 618 spider crab Libinia ferreirae (Brachyura: Majoidea): ontogenetic shifts in habitat use.

619 Hydrobiologia 795: 313-325. DOI: 10.1007/s10750-017-3153-z.

620 Gonçalves GRL, Wolf MR, da Costa RC, Castilho AL. 2016. Decapod crustacean associations 621 with scyphozoan jellyfish (Rhizostomeae: Pelagiidae) in the Southeastern Brazilian coast.

622 Symbiosis 69:193-198. DOI: 10.1007/s13199-016-0395-x.

623 Grabe SA, Lees DC. 1995. Macrozooplankton studies in Kuwait Bay (Arabian Gull). III. 624 Distribution and composition of larval pleocyemate decapod Crustacea. Journal of Plankton 625 Research 17:955-963. DOI: 10.1093/plankt/17.5.955.

626 Graham WM. 1989. Long-term association of Cancer sp. crabs with scyphomedusae in 627 Monterey Bay. Abstract of the VInternational Conference on Coelenterate Biology,

628 Southampton. 38-39 pp

629 Graham WM. 1994. The physical oceanography and ecology of upwelling shadows. D. Phil.

630 Thesis, University of California.

631 Graham WM, Bayha KM. 2007. Biological Invasions by Marine Jellyfish. In: Biological 632 Invasions. Springer Berlin Heidelberg, 239-255. DOI: 10.1007/978-3-540-36920-2_14. 
633 Greer AT, Briseno-Avena C, Deary AL, Cowen RK, Hernandez FJ, Graham WM. 2017.

634 Associations between lobster phyllosoma and gelatinous zooplankton in relation to

635 oceanographic properties in the northern Gulf of Mexico. Fisheries Oceanography 29: 693-704.

636 DOI: $10.1111 /$ fog. 12228.

637 Guinotte JM, Fabry VJ. 2008. Ocean acidification and its potential effects on marine ecosystems. 638 Annals of the New York Academy of Sciences 1134:320-342. DOI: 10.1196/annals.1439.013.

639 Gutsell JS. 1928. The Spider Crab, Libinia dubia, and the Jelly-fish, Stomolophus meleagris, 640 found associated at Beauford, North Carolina. Ecology 9:358-359. DOI: 10.2307/1932377.

641 Hayashi K, Miyake S. 1968. Three Caridean shrimps associated with a medusa from Tanabe 642 Bay, Japan. Publications of the Seto Marine Biological Laboratory 16: 11-19

643 Hayashi K, Sakagami J, Toyoda Y. A jellyfish shrimp associated with the Echizen jellyfish from 644 the Pacific coast of the Sea of Japan and the Tohoku region. Cancer 13: 9-15.

645 Hays GC, Doyle TK, Houghton JDR. 2018. A Paradigm Shift in the Trophic Importance of 646 Jellyfish? Trends in Ecology and Evolution. DOI: 10.1016/j.tree.2018.09.001.

647 Henschke N, Smith JA, Everett JD, Suthers IM. 2014. Population drivers of a Thalia 648 democratica swarm: Insights from population modelling. Journal of Plankton Research 649 37:1074-1087. DOI: 10.1093/plankt/fbv024.

650 Herrnkind W, Halusky J, Kanciruk P. 1976. A further note on Phyllosoma larvae associated with 651 medusae. Bulletin of Marine Science 26(1).

652 Hiro F. 1937. Studies on Cirripedian Fauna of Japan II. Cirripeds Found in the Vicinity of the 653 Seto Marine Biological Laboratory. Memoirs of the College of Science, Kyoto Imperial 654 University, Series B (1937) 12(3): 385-478

655 Hughes LE, Lindsay D. 2017. Pseudocallisoma coecum (Holmes, 1908) (Amphipoda, 656 Scopelocheiridae) and Lanceola clausi clausi Bovallius, 1885 (Amphipoda, Lanceolidae) 657 associated with Poralia rufescens Vanhöffen, 1902 (Scyphozoa, Ulmaridae). Crustaceana 658 90:1303-1318. DOI: 10.1163/15685403-00003709.

659 Humes AG. 1953. Two new semiparasitic harpacticoid copepods from the coast of New 660 Hampshire. Journal of the Washington Academy of Sciences 43:360-373. DOI:

$66110.2307 / 24533339$.

662 Humes AG. 1969. A cyclopoid copepod, Sewellochiron fidens n. gen., n. sp., associated with a 663 medusa in Puerto Rico. Beauforita 16:171-183.

664 Humes AG. 1970. Paramacrochiron japonicum n. sp., a cyclopoid copepod associated with a 665 medusa in Japan. Publications of the Seto Marine Biological Laboratory 18:223-232.

666 Jachowski R. 1963. Observations on the moon jelly, Aurelia aurita, and the spider crab, Libinia 667 dubia. Chesapeake Science 4:195-195. DOI: 10.2307/1351361.

668 Kishinouye K. 1902. Some medusae of Japanese waters. Journal of the College of Science, 669 Imperial University, Tokyo 17:1-35.

670 Kondo Y, Ohtsuka S, Nishikawa J, Metillo E, Pagliawan H, Sawamoto S, Moriya M, Nishida S, 
671 Urata M. 2014. Associations of fish juveniles with rhizostome jellyfishes in the Philippines, with 672 taxonomic remarks on a commercially harvested species in Carigara Bay, Leyte Island. Plankton 673 and Benthos Research 9:51-56. DOI: 10.3800/pbr.9.51.

674 Larson RJ. 1990. Scyphomedusae and cubomedusae from the eastern Pacific. Bulletin of Marine 675 Science 47:546-556.

676 de Lima MCG, Valentin JL. 2001. New records of Amphipoda Hyperiidea in associations with 677 gelatinous zooplankton. Hydrobiologia 448:229-235. DOI: 10.1023/A:1017593120143.

678 Lindsay DJ, Furushima Y, Miyake H, Kitamura M. 2004. The scyphomedusan fauna of the 679 Japan Trench: preliminary results from a remotely-operated vehicle. Hydrobiologia. DOI: 680 10.1007/978-1-4020-2762-8.

681 Lindsay D, Pagès F. 2010. Voragonema tatsunoko (Trachymedusae: Rhopalonematidae), a new 682 species of benthopelagic medusa, host to the hyperiid amphipod Mimonectes spandli 683 (Physosomata: Mimonectidae). Zootaxa 2671:31-39.

684 Liu RY, Ren XQ. 1985. Studies on Chinese Cirripedia (Crustacea). VI. Suborder Lepadomorpha. 685 Studia Marina Sinica 25:179-281.

686 Lopes L de A, Cutrim SSJ, Lyra FAT. 2008. Primeiro registro da associao entre o Caranguejo 687 Libinia ferreirae (Crustacea; Decapoda; Majidae) e a medusa Lychnorhiza lucerna (Cnidaria; 688 Scyphozoa; Rhizostmeae) para o Golfao Maranhense. Boletim do Laboritorio de Hidrobiologia 68921.

690 Martin J, Kuck H. 1991. Faunal Associates of an Undescribed Species of Chrysaora (Cnidaria, 691 Scyphozoa) in the Southern California Bight, with Notes on Unusual Occurrences of Other 692 Warm Water Species in the Area. Bull-Southern California Acad. Sci 90:89-101. DOI:

$69310.1017 /$ CBO9781107415324.004.

694 Mazda Y, Sasagawa T, Iinuma Y, Wakabayashi K. 2019. Maternal care and juvenile feeding in a 695 hyperiid amphipod (Oxycephalus clausi Bovallius, 1887) in association with gelatinous 696 zooplankton. Marine Biology Research 15(10): 541-547.

697 Mir-Arguimbau J, Sabatés A, Tilves U. 2019. Trophic ecology of Trachurus mediterraneus 698 juveniles associated with the jellyfish Rhizostoma pulmo and Cotylorhiza tuberculata. Journal of 699 Sea Research 147:28-36. DOI: 10.1016/j.seares.2019.02.004.

700 de Moraes IRR, Wolf MR, Gonçalves GRL, Castilho AL. 2017. Fecundity and reproductive 701 output of the caridean shrimp Periclimenes paivai associated with scyphozoan jellyfish.

702 Invertebrate Reproduction and Development 61:71-77. DOI: 10.1080/07924259.2017.1282890.

703 Morandini AC, Stampar SN, Maronna MM, Da Silveira FL. 2017. All non-indigenous species 704 were introduced recently? The case study of Cassiopea (Cnidaria: Scyphozoa) in Brazilian 705 waters. Journal of the Marine Biological Association of the United Kingdom 97:321-328. DOI: $70610.1017 / \mathrm{S} 0025315416000400$.

707 Moreira MGBS. 1961. Sobre Mastigias scintillae sp. nov. (Scyphomedusae, Rhizostomeae) das 708 costas do Brasil. Boletim do Instituto Oceanográfico 11:05-29. DOI: 10.1590/s037370955241961000100001. 
710 Morton B. 1989. Partnerships in the sea: Hong Kong's marine symbioses. Kent State University 711 Press.

712 Nogueira Junior M, E Silva JDL. 2005. Associações entre medusas (Cnidaria) e isópodos

713 (Crustacea) nos litorais do Paraná e Santa Catarina, Brasil. Acta Biológica Paranaense 34:127-

714 138. DOI: 10.5380/abpr.v34i0.959.

715 Nogueira Júnior M, Haddad MA. 2005. Lychnorhiza lucerna Haeckel (Scyphozoa,

716 Rhizostomeae) and Libinia ferreirae Brito Capello (Decapoda, Majidae) association in southern

717 Brazil. Revista Brasileira de Zoologia 22:908-912. DOI: 10.1590/s0101-81752005000400015.

718 Ohtsuka S, Boxshall GA, Srinui K. 2012. A new species of Paramacrochiron (Copepoda:

719 Cyclopoida: Macrochironidae) associated with the rhizostome medusa Rhopilema hispidum

720 collected from the Gulf of Thailand, with a phylogenetic analysis of the family Macrochironidae

721 .Zoological Science 29:127-133. DOI: 10.2108/zsj.29.127.

722 Ohtsuka S, Koike K, Lindsay D, Nishikawa J, Miyake H, Kawahara M, Mulyadi, Mujiono N,

723 Hiromi J, Komatsu H. 2009. Symbionts of marine medusae and ctenophores. Plankton and

724 Benthos Research 4:1-13. DOI: 10.3800/pbr.4.1.

725 Ohtsuka S, Kondo Y, Sakai Y, Shimazu T. 2010. In-situ Observations of Symbionts on Medusae

726 Occurring in Japan, Thailand, Indonesia and Malaysia. Bulletin of the Hiroshima University

727 Museum 2:9-18.

728 Ohtsuka S, Kondo Y, Iwasaki S, Hayashi K. 2011. Caridean shrimps associated with the

729 rhizostome jellyfish Netrostoma setouchiana in the central part of the Seto Inland Sea, Japan.

730 Bulletin of the Hiroshima University Museum 3: 1-6.

731 Oliva ME, Maffet A, Laudien J. 2010. Asociación entre Chrysaora plocamia (Cnidaria,

732 Scyphozoa) e Hyperia curticephala (Peracarida: Amphipoda) en Bahía de Mejillones, norte de

733 Chile. Revista de Biologia Marina y Oceanografia 45:127-130. DOI: 10.4067/S0718-

73419572010000100012.

735

736

737

738

739

740

741

742

743

744

745

746

747

748

Omori M, Nakano E. 2001. Jellyfish fisheries in southeast Asia. Hydrobiologia 451:19-26. DOI: 10.1023/A:1011879821323.

Pagès F. 2000. Biological associations between barnacles and jellyfish with emphasis on the ectoparasitism of Alepas pacifica (Lepadomorpha) on Diplulmaris malayensis (scyphozoa). Journal of Natural History 34:2045-2056. DOI: 10.1080/002229300750022349.

Panikkar N, Raghu Prasad R. 1952. Interesting association of ophiuroids, fish and crab with the jellyfish Rhopilema hispidum. Journal of The Bombay Natural History Society 51:295-296.

Phillips PJ, Burke WD, Keener EJ. 1969. Observations on the Trophic Significance of Jellyfishes in Mississippi Sound with Quantitative Data on the Associative Behavior of Small Fishes with Medusae. Transactions of the American Fisheries Society 98:703-712. DOI: 10.1577/15488659(1969)98.

Puente-Tapia FA, Gasca R, Genzano G, Schiariti A, Morandini AC. 2018. New records of association between Brachyscelus cf. rapacoides (Arthropoda: Amphipoda) and medusae (Cnidaria: Scyphozoa and Hydrozoa) from São Sebastião Channel, southeast Brazil. Brazilian 
750

751

752

753

754

755

756

757

758

759

760

761

762

763

764

765

766

767

768

769

770

771

772

773

774

775

776

777

778

779

780

781

782

783

784

785

786

Journal of Oceanography 66:301-306.

Reddiah K. 1968. Three New Species of Paramacrochiron ( Lichomolgidae ) Associated with Medusae. Crustaceana 1:193-209.

Reddiah K. 1969. Pseudomacrochiron Stocki n. g.., n. sp., a cyclopoid copepod associated with a medusa. Crustaceana 16:43-50. DOI: 10.1163/156854068X00160.

Riascos JM, Aguirre W, Hopfe C, Morales D, Navarrete Á, Tavera J. 2018. Floating nurseries? Scyphozoan jellyfish, their food and their rich symbiotic fauna in a tropical estuary. PeerJ. DOI: 10.7717/peerj.5057.

Riascos JM, Villegas V, Cáceres I, Gonzalez JE, Pacheco AS. 2013. Patterns of a novel association between the scyphomedusa Chrysaora plocamia and the parasitic anemone Peachia chilensis. Journal of the Marine Biological Association of the United Kingdom 93:919-923. DOI: $10.1017 / \mathrm{S} 002531541200094 \mathrm{X}$.

Rountree RA. 1983. The Ecology of Stomolophus meleagris, the cannon ball jellyfish, and its symbionts, with special emphasis on behavior. Honors Thesis, UNC Wilmington.

Schiariti A, Sal Moyano MP, Giberto DA, Diaz Briz L, Gavio MA, Mianzan HW. 2012. The symbiotic relationship between Lychnorhiza lucerna (Scyphozoa, Rhizostomeae) and Libinia spinosa (Decapoda, Epialtidae) in the Río de la Plata (Argentina-Uruguay). Marine Biology 159:1933-1941. DOI: 10.1007/s00227-012-1980-z.

Shanks AL, Graham WM. 1988. Chemical defense in a scyphomedusa. Marine Ecology Progress Series 45:81-86.

Suzuki K. 1965. On a young crab found near the oral arms of the jellyfish, Rhopilema esculenta Kishinouye. Res Crustac (Kokakurui no Kenkyu) 2:77-82.

Sweetman AK, Chelsky A, Pitt KA, Andrade H, van Oevelen D, Renaud PE. 2016. Jellyfish decomposition at the seafloor rapidly alters biogeochemical cycling and carbon flow through benthic food-webs. Limnology and Oceanography 61:1449-1461. DOI: 10.1002/lno.10310.

Tahera Q and Kazmi QB. 2006. New records of two jellyfish medusae (Cnidaria: Scyphozoa: Catostylidae: Cubozoa: Chirodropidae) from Pakistani waters. Marine Biodiversity Records 1: e30 DOI: $10.1017 /$ S1755267206002983.

Thiel ME. 1976. Wirbellose Meerestiere als Parasiten, Kommensalen oder Symbionten in oder an Scyphomedusen. Helgoländer Wissenschaftliche Meeresuntersuchungen 28:417-446. DOI: 10.1007/BF01610591.

Thomas LR. 1963. Phyllosoma larvae associated with medusae. Nature, 198: 208.

Tilves U, Sabatés A, Blázquez M, Raya V, Fuentes VL. 2018. Associations between fish and jellyfish in the NW Mediterranean. Marine Biology 165:1-14. DOI: 10.1007/s00227-018-33814.

Torchin ME, Lafferty KD, Dobson AP, McKenzie VJ, Kuris AM. 2003. Introduced species and their missing parasites. Nature 421:628-630. DOI: 10.1038/nature01346.

Towanda T, Thuesen E V. 2006. Ectosymbiotic behavior of Cancer gracilis and its trophic 
787 relationships with its host Phacellophora camtschatica and the parasitoid Hyperia medusarum.

788 Marine Ecology Progress Series 315:221-236. DOI: 10.3354/meps315221.

789 Trott LB. 1972. The portunid crab Charybdis feriatus (Linnaeus) commensal with the

790 scyphozoan jellyfish Stomolophus nomurai (Kishinouye) in Hong Kong. Crustaceana 23:305-

791306.

792 Tubb, J. A., 1946. On the occurrence of Alepas pacifica Pilsbry in Tasmania. Records of the

793 Australian Museum 21(7): 383-385. DOI: 10.3853/j.0067-1975.21.1946.554Tunberg B, Reed S.

794 2004. Mass occurrence of the jellyfish Stomolophus meleagris and an associated spider crab

795 Libinia dubia, Eastern Florida. Florida Scientist 67.

796 Utinomi H. 1958. Studies on the Cirripedean fauna of Japan -VII. Cirripeds from Sagami Bay.

797 Publications of the Seto Marine Biological Laboratory 6:281-311. DOI: 10.5134/175313.

798 Utinomi H. 1968. Pelagic, shelf and shallow-water Cirripedia from the Indo-Westpacific.

799 Videnskabelige Meddelelser fra dansk naturhistorisk Forening 131:2045-2056.

800 Uye SI. 2008. Blooms of the giant jellyfish Nemopilema nomurai: A threat to the fisheries

801 sustainability of the East Asian Marginal Seas. Plankton and Benthos Research 3:125-131. DOI:

$80210.3800 /$ pbr.3.125.

803 Vader W. 1972. Associations between gammarid and caprellid amphipods and medusae. Sarsia

804 50:51-56. DOI: 10.1080/00364827.1972.10411217.

805 Vaz-Ferreira C. 1972. Relaciones de conveniencia entre Libinia spinosa Milne Edwards

806 (Decapoda, Brachyura) y Discomedusae. Bol. Soc. Zool 2:64-66.

807 Wakabayashi K, Tanaka Y, Phillips BF. 2019. Culture of Slipper Lobster Larvae

808 (Decapoda: Achelata: Scyllaridae) Fed Jellyfish as Food. In: Radhakrishnan EV et al., ed. 1.

809 Lobsters: Biology, Fisheries and Aquaculture. Springer Nature Singapore Pte Ltd. 519-540.

810 Walther G-R, Post E, Convey P, Menzel A, Parmesan C, Beebee TJC, Fromentin J-M, Hoegh-

811 Guldberg O, Bairlein F. 2002. Ecological responses to recent climate change. Nature 416:389-

812 395. DOI: 10.1038/416389a.

813 Weymouth FW. 1910. Synopsis of the True Crabs(Brachyura) of Monterey Bay California. Palo

814 Alto: Stanford University.

815 Wrobel D, Mills C. 1998. Coast Pelagic Invertebrates-A Guide to the Common Gelatinous

816 Animals. Monterey: Sea Challengers.

817 Yusa Y, Yamato S, Kawamura M, Kubota S. 2015. Dwarf males in the barnacle Alepas pacifica

818 Pilsbry, 1907 (Thoracica, Lepadidae), a symbiont of jellyfish. Crustaceana 88:273-282. DOI:

$81910.1163 / 15685403-00003414$.

820 Zamponi MO. 2002. The association between medusa Lychnorhiza lucerna (Scyphomedusae,

821 Rhizostomeae) and decapod Libinia spinosa (Brachyura, Majidae) recorded for the first time in

822 neritic waters of Argentina. Russian Journal of Marine Biology 28:267-269. DOI:

823 10.1023/A:1020229328660.

824

Peer] reviewing PDF | (2020:12:56424:2:0:NEW 10 Mar 2021) 


\section{Figure 1}

Summary of Google Search Results

The number of results reported by Google Scholar Advanced Search where both "Crustacea" and one of the four medusa describer terms was included ("Hydrozoa", "Scyphozoa", "medusa", or "jellyfish") and at least one of the following terms was included (Association, Associated, Symbiotic, Symbiosis, Commensal, Epifaunal, Harboring, Parasitic, Parasitoid, Epibiont or Epibiotic).




Figure 2

Diversity of Scyphozoa and Hydrozoa species

Rings from innermost to outermost are order, family, genus in the classes (A) Scyphozoa and (B) Hydrozoa as distributed by number of accounts including a host in that group. Families and genera with single reports are whitened. 





Figure 3

Diversity of Crustacean epibionts

From innermost ring to outermost ring: Subphylum, Order, Family, Genus. Color coded by classes Malacostraca (orange), Hexanauplia (pink), and Brachipoda (green). Families and genera reported only once are whitened. 


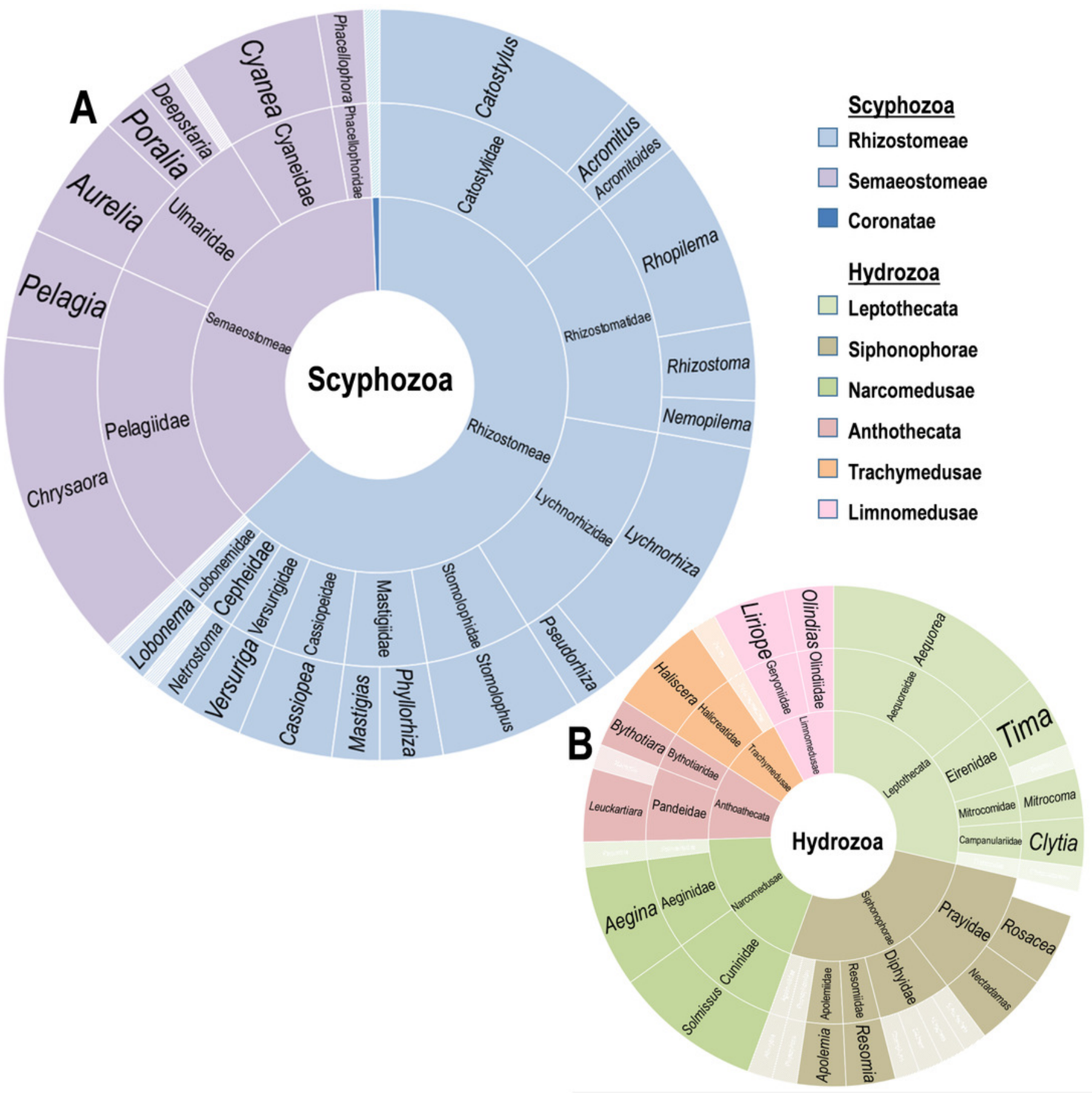




\section{Figure 4}

Collections information for both number of papers using a collection method and number of associations reported from this collection type

Types are blue water diving (BWD), collection by hand (HC), multiple methods (MULTI), ring net (RN), scuba diving (SC), trawling (TR), in situ observation (OBS) or unknown (Unknown). Associations from papers in which multiple methods were used, but specific methods are known for each association are categorized under the known method. Many papers are comprised of multiple associations, as such, the "Individual" columns include each association separately, "Paper" columns report by paper.

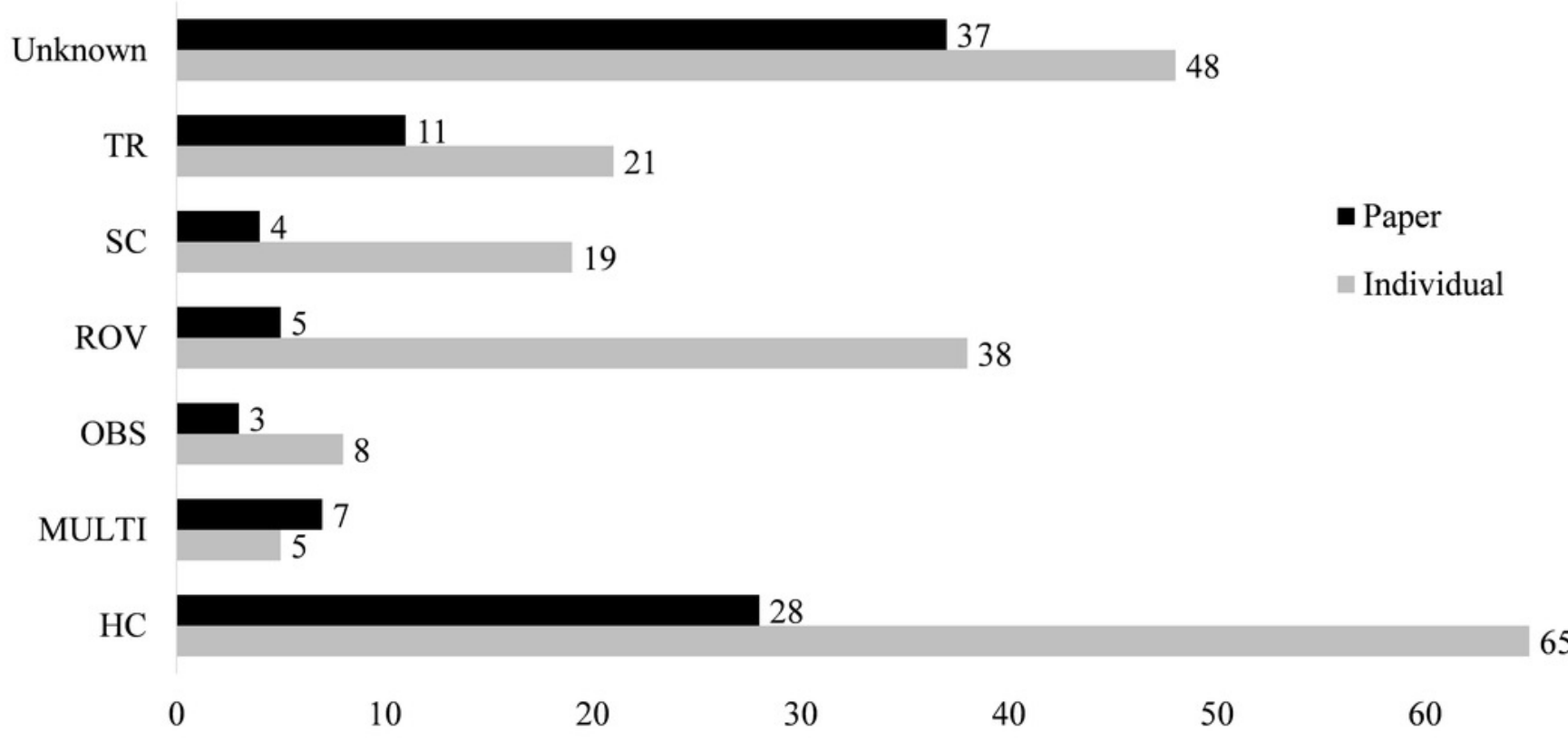


Figure 5

Percent of sampling by depth

The depths of samples with known depths. $68 \%$ of samplings had known depth data (pie chart). $74.4 \%$ of sampling was done above $30 \mathrm{~m}$. Where depth ranges were given (i.e. 8 to 30 meters) the deeper value was used. 


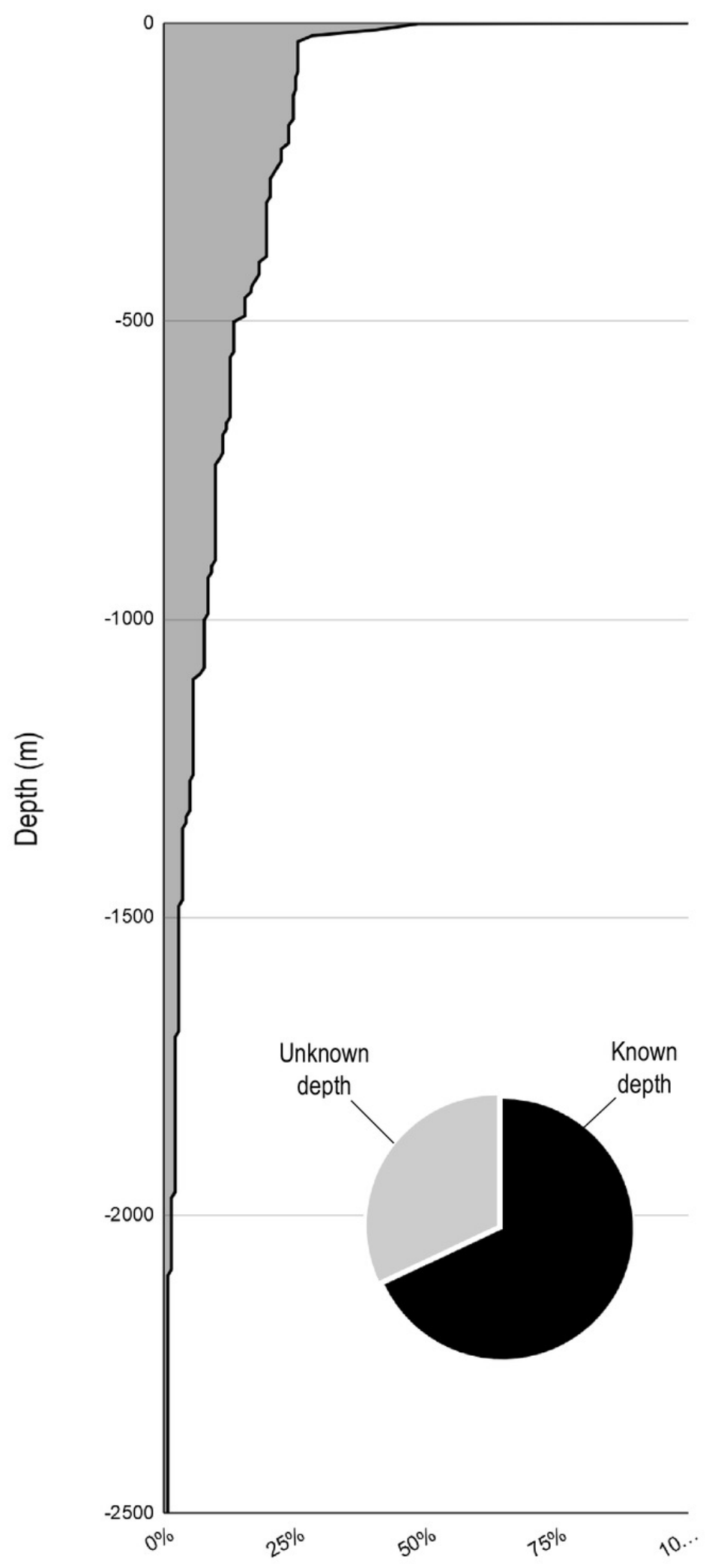




\section{Table $\mathbf{1}$ (on next page)}

\section{Associations Reported Organized By Host}

Every association in all reviewed papers with details on species and higher order classification of host, species of associate, sex and life stage of associate, notes on association, location on host, location association was recorded, date of record, depth of association and literature source. 
Table 1: Associations Reported Organized By Host

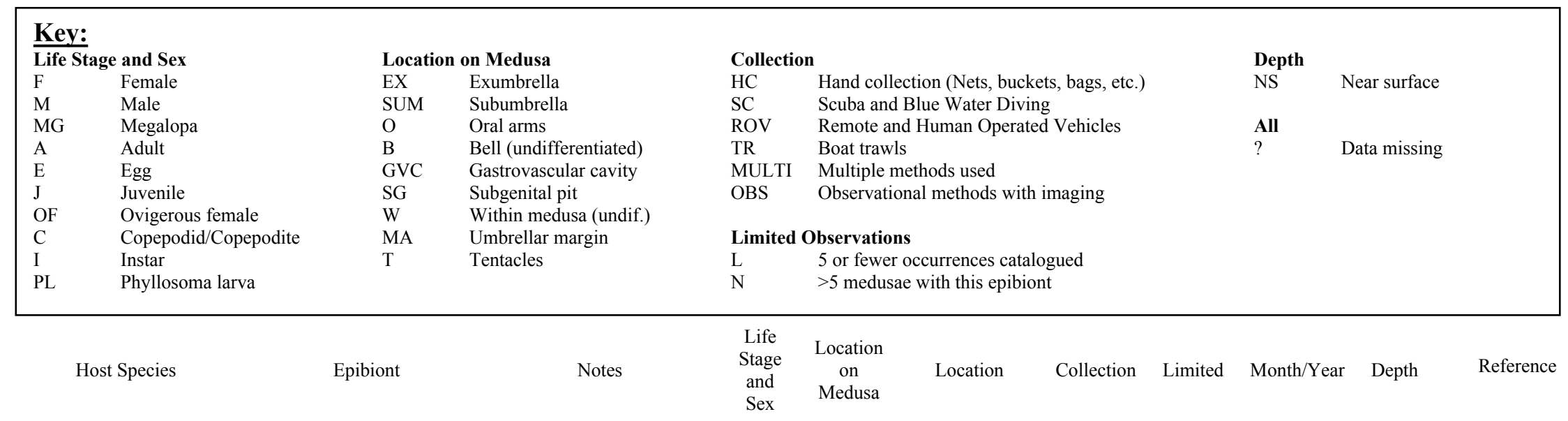

\section{Scyphozoa}

Coronatae

\begin{tabular}{|c|c|c|c|c|c|c|c|c|c|c|}
\hline $\begin{array}{l}\text { Nausithoe rubra Vanhöffen, } \\
1902\end{array}$ & $\begin{array}{l}\text { Prohyperia shihi Gasca, } \\
2005\end{array}$ & $\begin{array}{l}\text { Not visibly parasitizing } \\
\text { host, female and male pair }\end{array}$ & $\mathrm{F}, \mathrm{M}$ & EX & $\begin{array}{l}\text { Gulf of } \\
\text { California }\end{array}$ & ROV & $\mathrm{L}$ & $2012 \mathrm{Feb}$ & $907 \mathrm{~m}$ & Gasca, 2013 \\
\hline \multicolumn{11}{|l|}{ Rhizostomeae } \\
\hline $\begin{array}{l}\text { Acromitoides purpurus } \\
\text { Mayer, } 1910\end{array}$ & $\begin{array}{l}\text { Charybdis feriata } \\
\text { Linnaeus, } 1758\end{array}$ & $\begin{array}{l}\text { Never more than one per } \\
\text { medusa }\end{array}$ & $?$ & $?$ & $\begin{array}{l}\text { Various bays, } \\
\text { Philippines }\end{array}$ & $\mathrm{HC}$ & $\mathrm{N}$ & $\begin{array}{l}\text { 2014-2015, } \\
\text { Feb-Apr }\end{array}$ & NS & $\begin{array}{l}\text { Boco \& Metillo, } \\
2018\end{array}$ \\
\hline $\begin{array}{l}\text { Acromitoides purpurus } \\
\text { Mayer, } 1910\end{array}$ & Paramacrochiron sp. & $\begin{array}{l}\text { Present } 44-100 \% \text { of } \\
\text { medusae depending on } \\
\text { location and medusa color } \\
\text { morph }\end{array}$ & $?$ & $?$ & $\begin{array}{l}\text { Various bays, } \\
\text { Philippines }\end{array}$ & $\mathrm{HC}$ & $\mathrm{N}$ & $\begin{array}{l}\text { 2014-2015, } \\
\text { Feb-Apr }\end{array}$ & NS & $\begin{array}{l}\text { Boco \& Metillo, } \\
2018\end{array}$ \\
\hline $\begin{array}{l}\text { Acromitus flagellatus Maas, } \\
1903\end{array}$ & $\begin{array}{l}\text { Latreutes anoplonyx } \\
\text { Kemp, } 1914\end{array}$ & N/A & $?$ & $?$ & Indonesia & ? & $?$ & $?$ & $?$ & Hayashi, 2004 \\
\hline Acromitus sp. & $\begin{array}{l}\text { Hourstonius pusilla K.H. } \\
\text { Barnard, } 1916\end{array}$ & $\begin{array}{l}\text { Present throughout the } \\
\text { adult medusa population }\end{array}$ & $?$ & SUM, O & $\begin{array}{l}\text { Chilka Lake, } \\
\text { India }\end{array}$ & $?$ & $\mathrm{~L}$ & $?$ & $?$ & $\begin{array}{l}\text { Chilton, } 1921 \\
\text { via Vader, } 1972\end{array}$ \\
\hline Cassiopea sp. & $\begin{array}{l}\text { Ancylomenes aqabai } \\
\text { Bruce, } 2008\end{array}$ & N/A & $\begin{array}{l}\text { OF \& } \\
\text { F }\end{array}$ & $\mathrm{O}$ & Aqaba, Jordan & $\mathrm{HC}$ & $\mathrm{L}$ & $1976 \mathrm{Mar}$ & NS & Bruce, 2008 \\
\hline Cassiopea sp. & $\begin{array}{l}\text { Ancylomenes holthuisi } \\
\text { Bruce, } 1969\end{array}$ & N/A & $?$ & $\mathrm{O}$ & $\begin{array}{l}\text { Zanzibar } \\
\text { harbour }\end{array}$ & $\mathrm{SC}$ & $\mathrm{L}$ & $1970 \mathrm{Dec}$ & $20-25 \mathrm{~m}$ & Bruce, 1972 \\
\hline Cassiopea sp. & $\begin{array}{l}\text { Periclimenes pedersoni } \\
\text { Chace, } 1958\end{array}$ & N/A & $\begin{array}{l}\text { OF \& } \\
\mathrm{M}\end{array}$ & $\mathrm{O}$ & $\begin{array}{l}\text { Santa Marta, } \\
\text { Colombia }\end{array}$ & $?$ & $\mathrm{~N}$ & $?$ & $3-40 \mathrm{~m}$ & Criales, 1984 \\
\hline
\end{tabular}




\begin{tabular}{|c|c|c|c|c|c|c|c|c|c|c|}
\hline Cassiopea sp. & $\begin{array}{l}\text { Periclimenes tonga } \\
\text { Bruce, } 1988\end{array}$ & N/A & OF & $?$ & $\begin{array}{l}\text { Nuapapu } \\
\text { Island } \\
\text { (southside), } \\
\text { Vava'u Group, } \\
\text { Tonga }\end{array}$ & ? & $\mathrm{L}$ & $1985 \mathrm{Jul}$ & ? & Bruce, 1988 \\
\hline Cassiopea sp. & $\begin{array}{l}\text { Periclimenes yucatanicus } \\
\text { Ives, } 1891\end{array}$ & N/A & $\begin{array}{l}\text { OF\& } \\
\text { jM \& } \\
\text { F }\end{array}$ & $\mathrm{O}$ & $\begin{array}{l}\text { Santa Marta, } \\
\text { Colombia }\end{array}$ & $?$ & $\mathrm{~N}$ & $?$ & $3-25 \mathrm{~m}$ & Criales, 1984 \\
\hline Cassiopea sp. & $\begin{array}{l}\text { Sewellochiron fidens } \\
\text { Humes, } 1969\end{array}$ & N/A & F, M & $?$ & Puerto Rico & $?$ & $?$ & 1959 & $3 \mathrm{~m}$ & Humes, 1969 \\
\hline $\begin{array}{l}\text { Catostylus mosaicus Quoy \& } \\
\text { Gaimard, } 1824\end{array}$ & Acartia sp. & N/A & $C \& A$ & $\mathrm{O}$ & $\begin{array}{l}\text { Botany Bay, } \\
\text { Lake Illawarra, } \\
\text { Smiths Lake, } \\
\text { New South } \\
\text { Wales }\end{array}$ & $\mathrm{HC}$ & $\mathrm{N}$ & $1999-2000$ & NS & $\begin{array}{l}\text { Browne \& } \\
\text { Kingsford, } 2005\end{array}$ \\
\hline $\begin{array}{l}\text { Catostylus mosaicus Quoy \& } \\
\text { Gaimard, } 1824\end{array}$ & $\begin{array}{l}\text { Cymodoce gaimardii } \mathrm{H} . \\
\text { Milne Edwards, } 1840\end{array}$ & Autumnal prevalence peak & $?$ & $\begin{array}{l}\text { O, } \\
\text { SUM, } \\
\text { EX }\end{array}$ & $\begin{array}{l}\text { Port Phillip } \\
\text { Bay,Victoria }\end{array}$ & $\mathrm{HC}$ & $\mathrm{N}$ & $\begin{array}{l}2009 \text { Aug - } \\
2010 \text { Sep }\end{array}$ & NS & Browne, 2015 \\
\hline $\begin{array}{l}\text { Catostylus mosaicus Quoy \& } \\
\text { Gaimard, } 1824\end{array}$ & $\begin{array}{l}\text { Cymodoce gaimardii } \mathrm{H} . \\
\text { Milne Edwards, } 1840\end{array}$ & Highest prevalence in Mar & A \& J & $\mathrm{B}, \mathrm{O}$ & $\begin{array}{l}\text { Port Phillip } \\
\text { Bay,Victoria }\end{array}$ & $\mathrm{HC}$ & $\mathrm{N}$ & $\begin{array}{l}2008 \text { Aug - } \\
2010 \text { Sep }\end{array}$ & NS & $\begin{array}{l}\text { Browne et al., } \\
2017\end{array}$ \\
\hline $\begin{array}{l}\text { Catostylus mosaicus Quoy \& } \\
\text { Gaimard, } 1824\end{array}$ & Evadne sp.. & Only one specimen & $?$ & $\mathrm{O}$ & $\begin{array}{l}\text { Botany Bay, } \\
\text { New South } \\
\text { Wales }\end{array}$ & $\mathrm{HC}$ & $\mathrm{L}$ & $1999-2000$ & NS & $\begin{array}{l}\text { Browne \& } \\
\text { Kingsford, } 2005\end{array}$ \\
\hline $\begin{array}{l}\text { Catostylus mosaicus Quoy \& } \\
\text { Gaimard, } 1824\end{array}$ & $\begin{array}{l}\text { Hyperia gaudichaudii } \mathrm{H} . \\
\text { Milne Edwards, } 1840\end{array}$ & $\begin{array}{l}\text { September prevalence } \\
\text { peak, Es and Js embedded } \\
\text { in host tissue }\end{array}$ & $\begin{array}{l}E \& J \\
\& A\end{array}$ & $\mathrm{GVC}, \mathrm{B}$ & $\begin{array}{l}\text { Port Phillip } \\
\text { Bay,Victoria }\end{array}$ & $\mathrm{HC}$ & $\mathrm{N}$ & $\begin{array}{l}2008 \text { Aug - } \\
2010 \text { Sep }\end{array}$ & NS & Browne, 2015 \\
\hline $\begin{array}{l}\text { Catostylus mosaicus Quoy \& } \\
\text { Gaimard, } 1824\end{array}$ & Ibacus sp. & $\begin{array}{l}\text { A single specimen from } \\
\text { Sydney museum collection }\end{array}$ & PL & SUB & $\begin{array}{l}\text { Hawkesbury } \\
\text { River, New } \\
\text { South Wales }\end{array}$ & $?$ & $\mathrm{~L}$ & 1925 & $?$ & Thomas, 1963 \\
\hline $\begin{array}{l}\text { Catostylus mosaicus Quoy \& } \\
\text { Gaimard, } 1824\end{array}$ & $\begin{array}{l}\text { Latreutes anoplonyx } \\
\text { Kemp, } 1914\end{array}$ & $\begin{array}{l}\text { Found on medusa type } \\
\text { specimen from Pakistan }\end{array}$ & $\begin{array}{l}\text { OF \& } \\
\mathrm{J}\end{array}$ & $\mathrm{O}$ & $\begin{array}{l}\text { Korangi Creek, } \\
\text { Pakistan }\end{array}$ & $\mathrm{HC}$ & $\mathrm{L}$ & 1995 & NS & $\begin{array}{l}\text { Tahera \& } \\
\text { Kazmi, } 2006\end{array}$ \\
\hline $\begin{array}{l}\text { Catostylus mosaicus Quoy \& } \\
\text { Gaimard, } 1824\end{array}$ & Lucifer $\mathrm{sp}$. & $\mathrm{N} / \mathrm{A}$ & $?$ & $\mathrm{O}$ & $\begin{array}{l}\text { Botany Bay, } \\
\text { Lake Illawarra, } \\
\text { New South } \\
\text { Wales }\end{array}$ & $\mathrm{HC}$ & $\mathrm{L}$ & $1999-2000$ & NS & $\begin{array}{l}\text { Browne \& } \\
\text { Kingsford, } 2005\end{array}$ \\
\hline $\begin{array}{l}\text { Catostylus mosaicus Quoy \& } \\
\text { Gaimard, } 1824\end{array}$ & Oithona sp.. & $\begin{array}{l}\text { Only present on two } \\
\text { medusae in one lake }\end{array}$ & $?$ & $\mathrm{O}$ & $\begin{array}{l}\text { Lake Illawarra, } \\
\text { New South } \\
\text { Wales }\end{array}$ & $\mathrm{HC}$ & $\mathrm{L}$ & $1999-2000$ & NS & $\begin{array}{l}\text { Browne \& } \\
\text { Kingsford, } 2005\end{array}$ \\
\hline $\begin{array}{l}\text { Catostylus mosaicus Quoy \& } \\
\text { Gaimard, } 1824\end{array}$ & Oncaea sp. & N/A & $?$ & $\mathrm{O}$ & $\begin{array}{l}\text { Botany Bay, } \\
\text { Smiths Lake, } \\
\text { New South } \\
\text { Wales }\end{array}$ & $\mathrm{HC}$ & $\mathrm{L}$ & $1999-2000$ & NS & $\begin{array}{l}\text { Browne \& } \\
\text { Kingsford, } 2005\end{array}$ \\
\hline $\begin{array}{l}\text { Catostylus mosaicus Quoy \& } \\
\text { Gaimard, } 1824\end{array}$ & $\begin{array}{l}\text { Oncaea venusta Philippi, } \\
1843\end{array}$ & N/A & $?$ & $\mathrm{O}$ & $\begin{array}{l}\text { Botany Bay, } \\
\text { Lake Illawarra, } \\
\text { New South } \\
\text { Wales }\end{array}$ & $\mathrm{HC}$ & $\mathrm{L}$ & $1999-2000$ & NS & $\begin{array}{l}\text { Browne \& } \\
\text { Kingsford, } 2005\end{array}$ \\
\hline
\end{tabular}




\begin{tabular}{|c|c|c|c|c|c|c|c|c|c|c|}
\hline $\begin{array}{l}\text { Catostylus mosaicus Quoy \& } \\
\text { Gaimard, } 1824\end{array}$ & $\begin{array}{l}\text { Paramacrochiron } \\
\text { maximum Thompson I.C. } \\
\text { \& Scott A., } 1903\end{array}$ & $\begin{array}{l}\text { Present in hundreds per } \\
\text { medusa at all phases of } \\
\text { development and size class }\end{array}$ & $\begin{array}{l}\mathrm{A} \& \mathrm{~J} \\
\& \mathrm{OF}\end{array}$ & $\mathrm{O}$ & $\begin{array}{l}\text { Botany Bay, } \\
\text { Lake Illawarra, } \\
\text { New South } \\
\text { Wales }\end{array}$ & $\mathrm{HC}$ & $\mathrm{N}$ & $1999-2000$ & NS & $\begin{array}{l}\text { Browne \& } \\
\text { Kingsford, } 2005\end{array}$ \\
\hline $\begin{array}{l}\text { Catostylus mosaicus Quoy \& } \\
\text { Gaimard, } 1824\end{array}$ & Pseudodiaptomus sp. & $\mathrm{N} / \mathrm{A}$ & A & $\mathrm{O}$ & $\begin{array}{l}\text { Botany Bay, } \\
\text { Lake Illawarra, } \\
\text { New South } \\
\text { Wales }\end{array}$ & $\mathrm{HC}$ & $\mathrm{N}$ & $1999-2000$ & NS & $\begin{array}{l}\text { Browne \& } \\
\text { Kingsford, } 2005\end{array}$ \\
\hline $\begin{array}{l}\text { Catostylus mosaicus Quoy \& } \\
\text { Gaimard, } 1824\end{array}$ & Temora sp. & $\mathrm{N} / \mathrm{A}$ & A & $\mathrm{O}$ & $\begin{array}{l}\text { Botany Bay, } \\
\text { Lake Illawarra, } \\
\text { Smiths Lake, } \\
\text { New South } \\
\text { Wales }\end{array}$ & $\mathrm{HC}$ & $\mathrm{N}$ & $1999-2000$ & NS & $\begin{array}{l}\text { Browne \& } \\
\text { Kingsford, } 2005\end{array}$ \\
\hline $\begin{array}{l}\text { Catostylus mosaicus Quoy \& } \\
\text { Gaimard, } 1824\end{array}$ & $\begin{array}{l}\text { Tortanus barbatus Brady, } \\
1883\end{array}$ & N/A & $C \& A$ & $\mathrm{O}$ & $\begin{array}{l}\text { Botany Bay, } \\
\text { Lake Illawarra, } \\
\text { New South } \\
\text { Wales }\end{array}$ & $\mathrm{HC}$ & $\mathrm{N}$ & $1999-2000$ & NS & $\begin{array}{l}\text { Browne \& } \\
\text { Kingsford, } 2005\end{array}$ \\
\hline Catostylus sp. & $\begin{array}{l}\text { Charybdis feriata } \\
\text { Linnaeus, } 1758\end{array}$ & Present from Apr-May & $?$ & O, SUM & $\begin{array}{l}\text { Kolambugan, } \\
\text { Lanao del } \\
\text { Norte }\end{array}$ & $?$ & $\mathrm{~N}$ & $\begin{array}{l}2013 \mathrm{Dec}- \\
2014 \mathrm{Jul}\end{array}$ & NS & $\begin{array}{l}\text { Boco et al., } \\
2014\end{array}$ \\
\hline Catostylus sp. & Paramacrochiron sp. & Present from Jan-Mar & $?$ & $\mathrm{O}, \mathrm{SUM}$ & $\begin{array}{l}\text { Kolambugan, } \\
\text { Lanao del } \\
\text { Norte }\end{array}$ & $\mathrm{HC}$ & $\mathrm{N}$ & $\begin{array}{l}2013 \mathrm{Dec}- \\
2015 \mathrm{Jul}\end{array}$ & NS & $\begin{array}{l}\text { Boco et al., } \\
2014\end{array}$ \\
\hline $\begin{array}{l}\text { Cephea cephea Forskål, } \\
1775\end{array}$ & $\begin{array}{l}\text { Alepas pacifica Pilsbry, } \\
1907\end{array}$ & $\begin{array}{l}\text { Barnacles } 44 \mathrm{~mm} \text { wide } \\
\text { present on umbrella and } \\
\text { oral arms. Additional } \\
\text { details absent. }\end{array}$ & $?$ & $\mathrm{~B}, \mathrm{O}$ & Japanese Coast & $?$ & $?$ & $?$ & $?$ & $\begin{array}{l}\text { Hiro, } 1937 \text { via } \\
\text { Pagès, } 2000\end{array}$ \\
\hline Lobonema sp. & Callinectes sp. & Instar $1 \mathrm{~cm}$ & MG, I & ? & $\begin{array}{l}\text { Gulf of } \\
\text { Tehuantepec }\end{array}$ & $?$ & $?$ & $?$ & ? & $\begin{array}{l}\text { Bieri unpubl. } \\
\text { data via } \\
\text { Towanda \& } \\
\text { Thuesen, } 2006\end{array}$ \\
\hline $\begin{array}{l}\text { Lobonemoides robustus } \\
\text { Stiasny, } 1920\end{array}$ & $\begin{array}{l}\text { Charybdis feriata } \\
\text { Linnaeus, } 1758\end{array}$ & $\begin{array}{l}\text { Present in Gulf of Thailand } \\
\text { from July to October as } \\
\text { well }\end{array}$ & $\mathrm{MG}, \mathrm{J}$ & $?$ & $\begin{array}{l}\text { Carigara Bay, } \\
\text { Leyte Island }\end{array}$ & $\mathrm{HC}$ & $\mathrm{L}$ & $\begin{array}{l}201323 \\
\text { August }\end{array}$ & NS & $\begin{array}{l}\text { Kondo et al., } \\
2014\end{array}$ \\
\hline $\begin{array}{l}\text { Lychnorhiza lucerna } \\
\text { Haeckel, } 1880\end{array}$ & $\begin{array}{l}\text { Cyrtograpsus affinis } \\
\text { Dana, } 1851\end{array}$ & N/A & A & SG & $\begin{array}{l}\text { Rio de la Plata } \\
\text { Estuary }\end{array}$ & TR & $\mathrm{N}$ & $2006 \mathrm{Mar}$ & $?$ & $\begin{array}{l}\text { Schiariti et al., } \\
2012\end{array}$ \\
\hline $\begin{array}{l}\text { Lychnorhiza lucerna } \\
\text { Haeckel, } 1880\end{array}$ & Grapsoidea gn sp. & N/A & $\mathrm{J}$ & $?$ & $\begin{array}{l}\text { Cananéia, } \\
\text { Brazil }\end{array}$ & TR & $\mathrm{L}$ & $\begin{array}{l}2013 \text { Feb- } \\
2014 \text { May }\end{array}$ & $5-15 \mathrm{~m}$ & $\begin{array}{l}\text { Gonçalves et al., } \\
2016\end{array}$ \\
\hline $\begin{array}{l}\text { Lychnorhiza lucerna } \\
\text { Haeckel, } 1880\end{array}$ & $\begin{array}{l}\text { Leander paulensis } \\
\text { Ortmann, } 1897\end{array}$ & $\mathrm{~N} / \mathrm{A}$ & M & $?$ & $\begin{array}{l}\text { Cananéia, } \\
\text { Brazil }\end{array}$ & TR & $\mathrm{L}$ & 2013-2014 & $5-15 \mathrm{~m}$ & $\begin{array}{l}\text { Gonçalves et al., } \\
2016\end{array}$ \\
\hline $\begin{array}{l}\text { Lychnorhiza lucerna } \\
\text { Haeckel, } 1880\end{array}$ & $\begin{array}{l}\text { Libinia dubia de Brito } \\
\text { Capello, } 1871\end{array}$ & $\begin{array}{l}40 \% \text { of individuals were } \\
\text { living on medusae, all } \\
\text { juveniles were living on }\end{array}$ & $\begin{array}{l}\mathrm{M}, \mathrm{F} \\
\mathrm{OF}, \mathrm{J}\end{array}$ & $\begin{array}{l}\mathrm{O}, \mathrm{SUB} \\
\mathrm{B}\end{array}$ & $\begin{array}{l}\text { Cananéia, } \\
\text { Brazil }\end{array}$ & $\mathrm{TR}$ & $\mathrm{N}$ & 2012 Jul & $5-15 \mathrm{~m}$ & $\begin{array}{l}\text { Gonçalves et al., } \\
2017\end{array}$ \\
\hline
\end{tabular}




\begin{tabular}{|c|c|c|c|c|c|c|c|c|c|c|}
\hline $\begin{array}{l}\text { Lychnorhiza lucerna } \\
\text { Haeckel, } 1880\end{array}$ & $\begin{array}{l}\text { Libinia ferreirae de Brito } \\
\text { Capello, } 1871\end{array}$ & N/A & $\mathrm{F}, \mathrm{M}, \mathrm{J}$ & $?$ & $\begin{array}{l}\text { Cananéia and } \\
\text { Rio de Janeiro } \\
\text { state, Macaé }\end{array}$ & TR & $\mathrm{N}$ & 2013-2014 & $5-15 \mathrm{~m}$ & $\begin{array}{l}\text { Gonçalves et al., } \\
2016\end{array}$ \\
\hline $\begin{array}{l}\text { Lychnorhiza lucerna } \\
\text { Haeckel, } 1880\end{array}$ & $\begin{array}{l}\text { Libinia ferreirae de Brito } \\
\text { Capello, } 1871\end{array}$ & N/A & $?$ & SUM, O & Maranhão state & $\mathrm{HC}$ & $\mathrm{N}$ & $\begin{array}{l}\text { 2005-2006 } \\
\text { Mar }\end{array}$ & $?$ & $\begin{array}{l}\text { Lopes et al., } \\
2008\end{array}$ \\
\hline $\begin{array}{l}\text { Lychnorhiza lucerna } \\
\text { Haeckel, } 1880\end{array}$ & $\begin{array}{l}\text { Libinia ferreirae de Brito } \\
\text { Capello, } 1871\end{array}$ & $\begin{array}{l}\text { Young crabs, transport and } \\
\text { protection }\end{array}$ & $\mathrm{J}, \mathrm{F}, \mathrm{M}$ & $\mathrm{SG}, \mathrm{O}$ & State of Paraná & $\mathrm{TR}$ & $\mathrm{N}$ & $\begin{array}{l}1997-2004 \\
\text { All yr }\end{array}$ & $8-30 \mathrm{~m}$ & $\begin{array}{l}\text { Nogueira Júnior } \\
\& \text { Haddad, } 2005\end{array}$ \\
\hline $\begin{array}{l}\text { Lychnorhiza lucerna } \\
\text { Haeckel, } 1880\end{array}$ & $\begin{array}{l}\text { Libinia spinosa Guérin, } \\
1832\end{array}$ & N/A & $\mathrm{F}$ & $?$ & Ubatuba & $\mathrm{TR}$ & $\mathrm{N}$ & $\begin{array}{l}2013 \text { Jul - } \\
2014 \text { Aug }\end{array}$ & $5-15 \mathrm{~m}$ & $\begin{array}{l}\text { Gonçalves et al., } \\
2016\end{array}$ \\
\hline $\begin{array}{l}\text { Lychnorhiza lucerna } \\
\text { Haeckel, } 1880\end{array}$ & $\begin{array}{l}\text { Libinia spinosa Guérin, } \\
1832\end{array}$ & $\begin{array}{l}\text { Dispersion, protection and } \\
\text { food particulate theft }\end{array}$ & $?$ & $?$ & Rio del Plata & MULTI & $\mathrm{N}$ & $\begin{array}{l}2007 \text { Jan- } \\
\text { Mar }\end{array}$ & $?$ & $\begin{array}{l}\text { Schiariti et al., } \\
2012\end{array}$ \\
\hline $\begin{array}{l}\text { Lychnorhiza lucerna } \\
\text { Haeckel, } 1880\end{array}$ & $\begin{array}{l}\text { Libinia spinosa Guérin, } \\
1832\end{array}$ & $\begin{array}{l}\text { Dispersion and food } \\
\text { particulate theft, Jan-Feb }\end{array}$ & $?$ & $?$ & Punta del Este & $?$ & $?$ & Jan-Feb & $?$ & $\begin{array}{l}\text { Vaz-Ferreira, } \\
1972 \text { via } \\
\text { Schiariti et al., } \\
2012\end{array}$ \\
\hline $\begin{array}{l}\text { Lychnorhiza lucerna } \\
\text { Haeckel, } 1880\end{array}$ & $\begin{array}{l}\text { Libinia spinosa Guérin, } \\
1832\end{array}$ & $\begin{array}{l}\text { Transportation and food } \\
\text { theft, no more than two } \\
\text { crabs/medusa }\end{array}$ & $?$ & SG & $\begin{array}{l}\text { Mar Chiquita } \\
\text { Estuary }\end{array}$ & $?$ & $\mathrm{~L}$ & $?$ & NS & $\begin{array}{l}\text { Zamponi, } 2002 \\
\text { via Schiariti et } \\
\text { al., } 2012\end{array}$ \\
\hline $\begin{array}{l}\text { Lychnorhiza lucerna } \\
\text { Haeckel, } 1880\end{array}$ & $\begin{array}{l}\text { Periclimenes paivai } \\
\text { Chace, } 1969\end{array}$ & $\begin{array}{l}72 \% \text { of collected medusae } \\
\text { had associate }\end{array}$ & $\begin{array}{l}\text { MG, } \\
\text { F, OF, } \\
\text { J }\end{array}$ & SUM & $\begin{array}{l}\text { Paraíba River } \\
\text { estuary }\end{array}$ & $\mathrm{HC}$ & $\mathrm{N}$ & 2016 Apr & NS & $\begin{array}{l}\text { Baeza et al., } \\
2017\end{array}$ \\
\hline $\begin{array}{l}\text { Lychnorhiza lucerna } \\
\text { Haeckel, } 1880\end{array}$ & $\begin{array}{l}\text { Periclimenes paivai } \\
\text { Chace, } 1969\end{array}$ & N/A & OF & SUM & Sao Paolo & TR & & $\begin{array}{l}2012 \text { Sep- } \\
\text { Oct }\end{array}$ & $5-15 \mathrm{~m}$ & $\begin{array}{l}\text { de Moraes et al., } \\
2017\end{array}$ \\
\hline $\begin{array}{l}\text { Lychnorhiza lucerna } \\
\text { Haeckel, } 1880\end{array}$ & $\begin{array}{l}\text { Periclimenes paivai } \\
\text { Chace, } 1969\end{array}$ & N/A & $\mathrm{OF}, \mathrm{M}$ & $?$ & Cananéia & TR & $\mathrm{N}$ & 2013-2014 & $5-15 \mathrm{~m}$ & $\begin{array}{l}\text { Gonçalves et al., } \\
2016\end{array}$ \\
\hline $\begin{array}{l}\text { Lychnorhiza lucerna } \\
\text { Haeckel, } 1880\end{array}$ & Periclimenes sp. & $\begin{array}{l}\text { Facultative commensal, } \\
\text { feeding on mucus, large } \\
\text { proportion ovigerous } \\
\text { females }\end{array}$ & $\begin{array}{l}\mathrm{OF}, \mathrm{A}, \\
\mathrm{J}\end{array}$ & SUM & São Paulo state & $\mathrm{HC}$ & $\mathrm{N}$ & $\begin{array}{l}\text { 1999-2002, } \\
2005 \text { Aug + } \\
2006 \text { Jul }\end{array}$ & NS & $\begin{array}{l}\text { Martinelli-Filho } \\
\text { et al., } 2008\end{array}$ \\
\hline $\begin{array}{l}\text { Lychnorhiza lucerna } \\
\text { Haeckel, } 1880\end{array}$ & $\begin{array}{l}\text { Synidotea marplatensis } \\
\text { Giambiagi, } 1922\end{array}$ & N/A & $?$ & $\begin{array}{l}\text { SG, O, } \\
\text { B }\end{array}$ & $\begin{array}{l}\text { Guaratuba, } \\
\text { Paraná e Barra } \\
\text { do Saí, Santa } \\
\text { Catarina }\end{array}$ & $\mathrm{TR}$ & $\mathrm{L}$ & $\begin{array}{l}\text { 2003-2004 } \\
\text { Aug-Dec }\end{array}$ & $8-14 \mathrm{~m}$ & $\begin{array}{l}\text { Nogueira Junior } \\
\& \text { E Silva, } 2005\end{array}$ \\
\hline $\begin{array}{l}\text { Lychnorhiza malayensis } \\
\text { Stiasny, } 1920\end{array}$ & $\begin{array}{l}\text { Paramacrochiron sewelli } \\
\text { Reddiah, } 1968\end{array}$ & $\begin{array}{l}100+\text { epibionts from } 5 \\
\text { hosts }\end{array}$ & $\mathrm{F}, \mathrm{M}$ & $?$ & $\begin{array}{l}\text { Ennore estuary } \\
\text { near Madras }\end{array}$ & $\mathrm{HC}$ & $\mathrm{L}$ & 1964 Apr & $?$ & Reddiah, 1968 \\
\hline $\begin{array}{l}\text { Mastigias papua Lesson, } \\
1830\end{array}$ & $\begin{array}{l}\text { Chlorotocella gracilis } \\
\text { Balss, } 1914\end{array}$ & $\begin{array}{l}\text { Collected from ten } \\
\text { medusae }\end{array}$ & $\begin{array}{l}\text { M, F, } \\
\text { OF }\end{array}$ & $\mathrm{O}$ & $\begin{array}{l}\text { Tanabe Bay, } \\
\text { Japan }\end{array}$ & ? & $\mathrm{N}$ & 1965 Oct & $?$ & $\begin{array}{l}\text { Hayashi and } \\
\text { Miyake, } 1968\end{array}$ \\
\hline $\begin{array}{l}\text { Mastigias papua Lesson, } \\
1830\end{array}$ & $\begin{array}{l}\text { Latreutes anoplonyx } \\
\text { Kemp, } 1914\end{array}$ & $\begin{array}{l}\text { Collected from ten } \\
\text { medusae }\end{array}$ & $\begin{array}{l}\mathrm{M}, \mathrm{F} \\
\mathrm{OF}\end{array}$ & $\mathrm{O}$ & $\begin{array}{l}\text { Tanabe Bay, } \\
\text { Japan }\end{array}$ & $?$ & $\mathrm{~N}$ & 1965 Oct & $?$ & $\begin{array}{l}\text { Hayashi and } \\
\text { Miyake, } 1968\end{array}$ \\
\hline $\begin{array}{l}\text { Mastigias papua Lesson, } \\
1830\end{array}$ & $\begin{array}{l}\text { Latreutes mucronatus } \\
\text { Stimpson, } 1860\end{array}$ & $\begin{array}{l}\text { Collected from ten } \\
\text { medusae }\end{array}$ & $\begin{array}{l}\text { M, F, } \\
\text { OF }\end{array}$ & $\mathrm{O}$ & $\begin{array}{l}\text { Tanabe Bay, } \\
\text { Japan }\end{array}$ & $?$ & $\mathrm{~N}$ & 1965 Oct & $?$ & $\begin{array}{l}\text { Hayashi and } \\
\text { Miyake, } 1968\end{array}$ \\
\hline $\begin{array}{l}\text { Nemopilema nотиrai } \\
\text { Kishinouye, } 1922\end{array}$ & $\begin{array}{l}\text { Alepas pacifica Pilsbry, } \\
1907\end{array}$ & Substrate & $\begin{array}{l}\mathrm{M}, \mathrm{F} \\
\mathrm{OF}\end{array}$ & B & $\begin{array}{l}\text { Western Coast } \\
\text { of Japan }\end{array}$ & $\mathrm{HC}$ & $\mathrm{N}$ & 2005-2009 & $?$ & $\begin{array}{l}\text { Yusa et al., } \\
2015\end{array}$ \\
\hline
\end{tabular}


Nemopilema nomurai Kishinouye, 1922

Nemopilema nomura Kishinouye, 1922

Netrostoma setouchianum

Kishinouye, 1902

Netrostoma setouchianum

Kishinouye, 1902

Phyllorhiza punctata von Lendenfeld, 1884

Phyllorhiza punctata von Lendenfeld, 1884

Phyllorhiza punctata von Lendenfeld, 1884

Phyllorhiza punctata von Lendenfeld, 1884

Pseudorhiza haeckeli Haacke, 1884

Pseudorhiza haeckel Haacke, 1884

Pseudorhiza haeckeli Haacke, 1884

Rhizostoma pulmo Macri, 1778

Rhizostoma pulmo Macri, 1778

Rhizostoma sp.

Rhizostoma sp.

Rhizostomatidae gn. sp.

Charybdis feriata
Linnaeus, 1758

Latreutes anoplonyx
Kemp, 1914
Chlorotocella gracilis
Balss, 1914
Latreutes mucronatus
Stimpson, 1860

Charybdis feriata

Linnaeus, 1758

Latreutes anoplonyx

Kemp, 1914

Libinia ferreirae de Brito Capello, 1871

Paramacrochiron sp.

Cymodoce gaimardii $\mathrm{H}$. Milne Edwards, 1840

Hyperia gaudichaudii $\mathrm{H}$. Milne Edwards, 1840

Themisto australis Stebbing, 1888

Hyperia galba Montagu, 1813

Iphimedia eblanae Spence Bate, 1857

Latreutes anoplonyx

Kemp, 1914

Paramacrochiron

rhizostomae Reddiah,

1968

Alepas pacifica Pilsbry,

1907
5 juveniles present on one host on the oral arms, one adult present under the bell of a second medusa.

Exhibits hiding behavior

Single specimen

Mix of sexes and ages of epibiont from two host

individuals, 7 on one and

54 epibionts on the other

Single specimen from

August 2014

N/A

Feb-Jul

Two specimens from Leyte Gulf- Guiuan in

April 2015

N/A

Exhibit cradle positioning for filter feeding

N/A

Peak in Oct, preference for mature medusae, consume host gonad

Present in the brachial

cavities, mouthpart shape leads to speculation that these are semi-parasitic short-term associates

N/A

N/A

2 barnacles on the

umbrellar margin up to 68 $\mathrm{mm}$ in length

\begin{tabular}{|c|c|c|c|c|c|c|c|}
\hline $\mathrm{J} \& \mathrm{M}$ & O, SUM & $\begin{array}{l}\text { Mirs Bay, } \\
\text { Hong Kong }\end{array}$ & $?$ & $\mathrm{~L}$ & 1970 Oct & $?$ & Trott, 1972 \\
\hline $\begin{array}{l}\mathrm{M}, \mathrm{F}, \\
\mathrm{OF}\end{array}$ & O, SUB & $\begin{array}{l}\text { Miyazu and } \\
\text { Sanriku, Japan } \\
\text { Seto Inland }\end{array}$ & $\begin{array}{l}\text { OBS. HC, } \\
\text { SC }\end{array}$ & $\mathrm{L}$ & 2003 Nov & $?$ & $\begin{array}{l}\text { Hayashi et al., } \\
2004 \\
\text { Ohtsuka et al., }\end{array}$ \\
\hline$?$ & $\mathrm{O}$ & $\begin{array}{l}\text { Sea, Japan } \\
\text { Seto Inland }\end{array}$ & $\mathrm{HC}$ & $\mathrm{L}$ & $2010 \mathrm{Sep}$ & NS & $\begin{array}{l}2011 \\
\text { Ohtsuka et al., }\end{array}$ \\
\hline $\mathrm{M}, \mathrm{F}$, & $\mathrm{O}$ & Sea, Japan & & $\mathrm{L}$ & 2010 Sep & NS & 2011 \\
\hline
\end{tabular}

Various bays, HC 2014-2015, NS L Boco \& Metillo,

Philippines

NT Australia $\quad \mathrm{HC}$

Feb-Apr

018

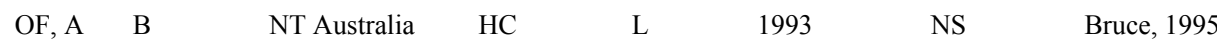

$\begin{array}{llllll}\text { ?? } & \text { SUM } & \text { Sao Paulo } & ? & ? & \text { Feb-Jul }\end{array}$

via Schiariti et

al., 2012

Boco \& Metillo,

2018

Browne, 2015

Browne, 2015

$\begin{array}{lll}\text { Port Phillip HC } & \text { N } & \text { 2009 Sep }+ \text { NS }\end{array}$

$2012 \mathrm{Feb}$

2010 Sep $+\quad$ NS

$2012 \mathrm{Feb}$

Port Phillip
Bay,Victoria

German Bight

$\mathrm{HC}+\mathrm{SC} \quad ?$

1984-1985 ?

NS

Dublin B

$\mathrm{N}$

Vader, 1972

Hayashi et al., 2004

Reddiah, 1968

Madras State

$1967 \mathrm{M}$

$?$

Morrison Bay, ?

Mergui Arch
Annandale,

1914 via Pagès,
2000 


\begin{tabular}{|c|c|c|c|c|c|c|c|c|c|c|}
\hline $\begin{array}{l}\text { Rhopilema esculentum } \\
\text { Kishinouye, } 1891\end{array}$ & $\begin{array}{l}\text { Charybdis feriata } \\
\text { Linnaeus, } 1758\end{array}$ & Juvenile transport & $\mathrm{J}$ & $\mathrm{O}$ & Sagami Bay & $?$ & $?$ & October & $?$ & $\begin{array}{l}\text { Suzuki, } 1965 \\
\text { via Pagès, } 2000\end{array}$ \\
\hline Rhopilema esculentum & Latreutes anoplonyx & N/A & $?$ & $?$ & Northeast & $?$ & $?$ & $?$ & $?$ & Hayashi et al., \\
\hline Kishinouye, 1891 & Kemp, 1914 & & & & China & & & & & 2004 \\
\hline Rhopilema hispidum & Charybdis annulata & N/A & $? ?$ & SUM & Palk Bay, Sri & $?$ & $\mathrm{~L}$ & $1950 \mathrm{Jul}$ & $?$ & Panikkar \& \\
\hline Vanhöffen, 1888 & Fabricius, 1798 & & & & Lanka & & & & & $\begin{array}{l}\text { Raghu Prasad, } \\
1952 \text { via } \\
\text { Towanda \& } \\
\text { Thuesen, } 2006\end{array}$ \\
\hline Rhopilema hispidum & Charybdis feriata & Present on all medusae & $\mathrm{J} \&$ & $?$ & Panguil Bay & $\mathrm{HC}$ & $\mathrm{N}$ & 2014 & NS & Boco \& Metillo, \\
\hline Vanhöffen, 1888 & Linnaeus, 1758 & collected in Aug & MG & & & & & Feb+Aug & & 2018 \\
\hline $\begin{array}{l}\text { Rhopilema hispidum } \\
\text { Vanhöffen, } 1888\end{array}$ & Hippolytidae gn sp. & $\begin{array}{l}\text { Three associates on a } \\
\text { single medusa from Feb }\end{array}$ & $?$ & $?$ & Panguil Bay & $\mathrm{HC}$ & $\mathrm{L}$ & $\begin{array}{l}2014 \\
\text { Feb+Aug }\end{array}$ & NS & $\begin{array}{l}\text { Boco \& Metillo, } \\
2018\end{array}$ \\
\hline $\begin{array}{l}\text { Rhopilema hispidum } \\
\text { Vanhöffen, } 1888\end{array}$ & $\begin{array}{l}\text { Latreutes sp.. aff. } \\
\text { anoplonyx Kemp, } 1914\end{array}$ & N/A & $? ?$ & MA, O & $\begin{array}{l}\text { Kukup, } \\
\text { Malaysia }\end{array}$ & $?$ & $\mathrm{~L}$ & $\begin{array}{l}2009 \mathrm{Mar}+ \\
\text { Oct }\end{array}$ & $?$ & $\begin{array}{l}\text { Ohtsuka et al., } \\
2010\end{array}$ \\
\hline $\begin{array}{l}\text { Rhopilema hispidum } \\
\text { Vanhöffen, } 1888\end{array}$ & $\begin{array}{l}\text { Latreutes sp.. aff. } \\
\text { anoplonyx Kemp, } 1914\end{array}$ & N/A & $? ?$ & $?$ & $\begin{array}{l}\text { Sichang Island, } \\
\text { Thailand }\end{array}$ & $?$ & $\mathrm{~L}$ & 2009 Oct & $?$ & $\begin{array}{l}\text { Ohtsuka et al., } \\
2010\end{array}$ \\
\hline $\begin{array}{l}\text { Rhopilema hispidum } \\
\text { Vanhöffen, } 1888\end{array}$ & Paramacrochiron sp. & $\begin{array}{l}\text { On } 67 \% \text { of medusae from } \\
\text { Aug collection }\end{array}$ & $?$ & $?$ & Panguil Bay & $\mathrm{HC}$ & $\mathrm{L}$ & $\begin{array}{l}2014 \\
\text { Feb+Aug }\end{array}$ & NS & $\begin{array}{l}\text { Boco \& Metillo, } \\
2018\end{array}$ \\
\hline $\begin{array}{l}\text { Rhopilema hispidum } \\
\text { Vanhöffen, } 1888\end{array}$ & Paramacrochiron sp. & $\begin{array}{l}\text { Theorized ectoparasite, no } \\
\text { record of actual } \\
\text { consumption. }\end{array}$ & A \& L & $\mathrm{O}$ & $\begin{array}{l}\text { Laem Phak } \\
\text { Bia, Thailand }\end{array}$ & $\mathrm{HC}$ & $\mathrm{L}$ & 2010 Oct & NS & $\begin{array}{l}\text { Ohtsuka et al., } \\
2012\end{array}$ \\
\hline $\begin{array}{l}\text { Rhopilema nomadica Galil, } \\
\text { Spanier \& Ferguson, } 1990\end{array}$ & $\begin{array}{l}\text { Charybdis feriata } \\
\text { Linnaeus, } 1758\end{array}$ & $\begin{array}{l}\text { Many hosts containing } \\
\text { multipe associations, only } \\
\text { some possess Charybdis, } \\
\text { never more than one crab } \\
\text { per medusa. }\end{array}$ & $?$ & $\mathrm{O}, \mathrm{SUB}$ & $\begin{array}{l}\text { Delagoa Bight, } \\
\text { Mozambique }\end{array}$ & $\mathrm{HC}$ & $\mathrm{L}$ & $\begin{array}{l}1988 \mathrm{Mar}+ \\
1992 \mathrm{Mar}\end{array}$ & NS & Berggren, 1994 \\
\hline $\begin{array}{l}\text { Rhopilema nomadica Galil, } \\
\text { Spanier \& Ferguson, } 1990\end{array}$ & $\begin{array}{l}\text { Periclimenes } \\
\text { nomadophila Berggren, } \\
1994\end{array}$ & $\begin{array}{l}\text { Many hosts containing } \\
\text { multipe associations. }\end{array}$ & $\begin{array}{l}\mathrm{F}, \mathrm{OF} \\
\mathrm{M}\end{array}$ & $\mathrm{O}, \mathrm{SUB}$ & $\begin{array}{l}\text { Delagoa Bight, } \\
\text { Mozambique }\end{array}$ & $\mathrm{HC}$ & $\mathrm{N}$ & $\begin{array}{l}1988 \mathrm{Mar}+ \\
1992 \mathrm{Mar}\end{array}$ & NS & Berggren, 1994 \\
\hline Rhopilema sp. & $\begin{array}{l}\text { Conchoderma virgatum } \\
\text { Spengler, } 1789\end{array}$ & $\begin{array}{l}22 \text { barnacles on the } \\
\text { umbrellar Margin (ex and } \\
\text { sub) on host of } 320 \mathrm{~mm} \\
\text { diameter }\end{array}$ & ? & MA & $\begin{array}{l}\text { Tranquebar, } \\
\text { Bengala Gulf }\end{array}$ & $?$ & $\mathrm{~L}$ & $?$ & ? & $\begin{array}{l}\text { Fernando \& } \\
\text { Ramamoorthi, } \\
1974 \text { via Pagès, } \\
2000\end{array}$ \\
\hline $\begin{array}{l}\text { Stomolophus meleagris, } \\
\text { Agassiz, } 1860\end{array}$ & $\begin{array}{l}\text { Charybdis feriata } \\
\text { Linnaeus, } 1758\end{array}$ & N/A & $F \& J$ & $\mathrm{O}$ & Hong Kong & $?$ & $?$ & $?$ & ? & $\begin{array}{l}\text { Morton, } 1989 \\
\text { via Towanda \& } \\
\text { Thuesen, } 2006\end{array}$ \\
\hline $\begin{array}{l}\text { Stomolophus meleagris, } \\
\text { Agassiz, } 1860\end{array}$ & $\begin{array}{l}\text { Conchoderma } \mathrm{cf} \\
\text { virgatum Spengler, } 1789\end{array}$ & $\begin{array}{l}\text { Mature jellyfish, scarring } \\
\text { and lesions around } \\
\text { attachment site }\end{array}$ & $?$ & B & $\begin{array}{l}\text { Gulf of } \\
\text { California }\end{array}$ & $\mathrm{HC}$ & $\mathrm{L}$ & $2010 \mathrm{Apr}$ & NS & $\begin{array}{l}\text { Álvarez-Tello et } \\
\text { al., } 2013\end{array}$ \\
\hline $\begin{array}{l}\text { Stomolophus meleagris, } \\
\text { Agassiz, } 1860\end{array}$ & $\begin{array}{l}\text { Libinia dubia } \text { H. Milne } \\
\text { Edwards, } 1834\end{array}$ & $\begin{array}{l}\text { All medusa harbored } \\
\text { crabs, no more than one }\end{array}$ & A & SUM & $\begin{array}{l}\text { Murrell's Inlet, } \\
\text { SC }\end{array}$ & ? & $\mathrm{N}$ & 1927 May & $\begin{array}{l}\text { "relatively } \\
\text { deep" }\end{array}$ & $\begin{array}{l}\text { Corrington, } \\
1927\end{array}$ \\
\hline
\end{tabular}




\begin{tabular}{|c|c|c|c|c|c|c|c|c|c|c|}
\hline $\begin{array}{l}\text { Stomolophus meleagris, } \\
\text { Agassiz, } 1860\end{array}$ & $\begin{array}{l}\text { Libinia dubia } \text { H. Milne } \\
\text { Edwards, } 1834\end{array}$ & $\mathrm{~N} / \mathrm{A}$ & $?$ & SUM & Beaufort, NC & TR & $\mathrm{N}$ & $\begin{array}{l}1927 \text { Jul- } \\
\text { Oct }\end{array}$ & NS & Gutsell, 1928 \\
\hline $\begin{array}{l}\text { Stomolophus meleagris, } \\
\text { Agassiz, } 1860\end{array}$ & $\begin{array}{l}\text { Libinia dubia } \mathrm{H} \text {. Milne } \\
\text { Edwards, } 1834\end{array}$ & $\begin{array}{l}\text { Juvenile associations, } \\
\text { parasitic, transient }\end{array}$ & $\mathrm{J}$ & W & $\begin{array}{l}\text { Mississippi } \\
\text { sound }\end{array}$ & $\mathrm{HC}$ & $\mathrm{N}$ & $\begin{array}{l}1968 \text { Jul- } \\
\text { Oct }\end{array}$ & NS & $\begin{array}{l}\text { Phillips et al., } \\
1969\end{array}$ \\
\hline $\begin{array}{l}\text { Stomolophus meleagris, } \\
\text { Agassiz, } 1860\end{array}$ & $\begin{array}{l}\text { Libinia dubia } \text { H. Milne } \\
\text { Edwards, } 1834\end{array}$ & $\begin{array}{l}\text { Highly variable seasonally, } \\
\text { high in July, low in Dec }\end{array}$ & $\mathrm{F}, \mathrm{M}, \mathrm{J}$ & $\mathrm{O}, \mathrm{MA}$ & $\begin{array}{l}\text { Wrightsville } \\
\text { Beach Jetty } \\
\text { NC }\end{array}$ & $\mathrm{HC}$ & $\mathrm{N}$ & $\begin{array}{l}1983 \text { May- } \\
\text { Dec }\end{array}$ & NS & Rountree, 1983 \\
\hline $\begin{array}{l}\text { Stomolophus meleagris, } \\
\text { Agassiz, } 1860\end{array}$ & $\begin{array}{l}\text { Libinia dubia } \mathrm{H} \text {. Milne } \\
\text { Edwards, } 1834\end{array}$ & Feeding & $?$ & EXC & $\begin{array}{l}\text { Onslow Bay, } \\
\text { NC }\end{array}$ & $\mathrm{SC}$ & $?$ & $? ?$ & $?$ & $\begin{array}{l}\text { Shanks \& } \\
\text { Graham, } 1988 \\
\text { via Schiariti et } \\
\text { al., } 2012\end{array}$ \\
\hline $\begin{array}{l}\text { Stomolophus meleagris, } \\
\text { Agassiz, } 1860\end{array}$ & $\begin{array}{l}\text { Libinia dubia } \mathrm{H} \text {. Milne } \\
\text { Edwards, } 1834\end{array}$ & N/A & $?$ & $?$ & $\begin{array}{l}\text { Indian River } \\
\text { Lagoon, } \\
\text { Florida }\end{array}$ & $\mathrm{HC}$ & $?$ & 2003 Mar & $?$ & $\begin{array}{l}\text { Tunberg \& } \\
\text { Reed, } 2004\end{array}$ \\
\hline $\begin{array}{l}\text { Stomolophus meleagris, } \\
\text { Agassiz, } 1860\end{array}$ & $\begin{array}{l}\text { Penaeus stylirostris } \\
\text { Stimpson, } 1871\end{array}$ & N/A & $?$ & $?$ & $\begin{array}{l}\text { Malaga Bay, } \\
\text { Colombia }\end{array}$ & $\mathrm{HC}$ & $?$ & $\begin{array}{l}2015 \mathrm{Nov}+ \\
2017 \mathrm{Apr}\end{array}$ & NS & $\begin{array}{l}\text { Riascos et al., } \\
2018\end{array}$ \\
\hline $\begin{array}{l}\text { Thysanostoma thysanura } \\
\text { Haeckel, } 1880\end{array}$ & Paramacrochiron sp. & N/A & ? & $?$ & Sirahama & $?$ & $?$ & 1969 & $?$ & Humes, 1970 \\
\hline $\begin{array}{l}\text { Versuriga anadyomene } \\
\text { Maas, } 1903\end{array}$ & $\begin{array}{l}\text { Charybdis feriata } \\
\text { Linnaeus, } 1758\end{array}$ & Large medusae & $?$ & $?$ & $\begin{array}{l}\text { Leyte Gulf- } \\
\text { Guiuan }\end{array}$ & $\mathrm{HC}$ & $\mathrm{L}$ & $\begin{array}{l}\text { 2014-2015, } \\
\text { Feb-Apr }\end{array}$ & NS & $\begin{array}{l}\text { Boco \& Metillo, } \\
2018\end{array}$ \\
\hline $\begin{array}{l}\text { Versuriga anadyomene } \\
\text { Maas, } 1903\end{array}$ & $\begin{array}{l}\text { Charybdis feriata } \\
\text { Linnaeus, } 1758\end{array}$ & N/A & $? ?$ & SUM & $\begin{array}{l}\text { Pari Island, } \\
\text { Indonesia }\end{array}$ & $?$ & $\mathrm{~L}$ & 2009 Nov & $?$ & $\begin{array}{l}\text { Ohtsuka et al., } \\
2012\end{array}$ \\
\hline $\begin{array}{l}\text { Versuriga anadyomene } \\
\text { Maas, } 1903\end{array}$ & $\begin{array}{l}\text { Latreutes anoplonyx } \\
\text { Kemp, } 1914\end{array}$ & N/A & A \& J & SUM & NT Australia & $\mathrm{HC}$ & $\mathrm{L}$ & 1993 & NS & Bruce, 1995 \\
\hline $\begin{array}{l}\text { Versuriga anadyomene } \\
\text { Maas, } 1903\end{array}$ & Paramacrochiron sp. & Large medusae & $?$ & $?$ & $\begin{array}{l}\text { Leyte Gulf- } \\
\text { Guiuan }\end{array}$ & $\mathrm{HC}$ & $\mathrm{N}$ & $\begin{array}{l}\text { 2014-2015, } \\
\text { Feb-Apr }\end{array}$ & NS & $\begin{array}{l}\text { Boco \& Metillo, } \\
2018\end{array}$ \\
\hline \multicolumn{11}{|l|}{ Semaeostomeae } \\
\hline $\begin{array}{l}\text { Aurelia aurita Linnaeus, } \\
1758\end{array}$ & $\begin{array}{l}\text { Hyperia galba Montagu, } \\
1813\end{array}$ & N/A & $\begin{array}{l}\text { A \& J } \\
\& \text { OF }\end{array}$ & $?$ & $\begin{array}{l}\text { Narragansett } \\
\text { Marine } \\
\text { Laboratory }\end{array}$ & $\mathrm{HC}$ & $?$ & 1955 June & NS & $\begin{array}{l}\text { Bowman et al., } \\
1963\end{array}$ \\
\hline $\begin{array}{l}\text { Aurelia aurita Linnaeus, } \\
1758\end{array}$ & $\begin{array}{l}\text { Hyperia galba Montagu, } \\
1813\end{array}$ & $\begin{array}{l}\text { Preference for mature } \\
\text { medusae, infestation } \\
\text { increases as gonads } \\
\text { develop, peak in Oct, } \\
\text { consume host gonad }\end{array}$ & $\mathrm{J}, \mathrm{A}$ & $\mathrm{O}$ & German Bight & $\mathrm{HC}+\mathrm{SC}$ & & $1984-1985$ & $?$ & Dittrich, 1988 \\
\hline $\begin{array}{l}\text { Aurelia aurita Linnaeus, } \\
1758\end{array}$ & $\begin{array}{l}\text { Libinia dubia } \text { H. Milne } \\
\text { Edwards, } 1834\end{array}$ & $\begin{array}{l}\text { Eating medusa tissue, } \\
\text { residence within bell, } \\
\text { excavation behaviors }\end{array}$ & $?$ & EXC & $\begin{array}{l}\text { Chesapeake } \\
\text { Bay }\end{array}$ & $?$ & $?$ & 1963 Aug & $?$ & Jachowski, 1963 \\
\hline $\begin{array}{l}\text { Aurelia aurita Linnaeus, } \\
1758\end{array}$ & Scyllarus sp. & $\begin{array}{l}19.9 \% \text { of medusae } \\
\text { examined } 300-500 \mathrm{~m} \text { from } \\
\text { shore had phyllosoma, } \\
\text { none on Aurelia near } \\
\text { shore, likely parasitoid. }\end{array}$ & PL & EX & $\begin{array}{l}\text { Bimini, } \\
\text { Bahamas }\end{array}$ & $\mathrm{HC}$ & $\mathrm{N}$ & 1973 Oct & NS & $\begin{array}{l}\text { Herrnkind et al., } \\
1976\end{array}$ \\
\hline
\end{tabular}




\begin{tabular}{|c|c|c|c|c|c|c|c|c|c|c|}
\hline $\begin{array}{l}\text { Aurelia coerulea von } \\
\text { Lendenfeld, } 1884\end{array}$ & $\begin{array}{l}\text { Ibacus ciliatus von } \\
\text { Siebold, } 1824\end{array}$ & $\begin{array}{l}\text { Riding small medusae, } \\
\text { pierced exumbrella with } \\
\text { pereiopods }\end{array}$ & PL & EX & $\begin{array}{l}\text { Yamaguchi, } \\
\text { Japan }\end{array}$ & OBS & $\mathrm{L}$ & $?$ & $?$ & $\begin{array}{l}\text { Wakabayashi et } \\
\text { al., } 2017 \text { via } \\
\text { Wakabayashi et } \\
\text { al. } 2019\end{array}$ \\
\hline $\begin{array}{l}\text { Aurelia coerulea von } \\
\text { Lendenfeld, } 1884\end{array}$ & $\begin{array}{l}\text { Oxycephalus } \\
\text { clausi Bovallius, } 1887\end{array}$ & $\begin{array}{l}\text { February to May, } 97.6 \% \\
\text { female, largely one female } \\
\text { per host, occasionally } \mathrm{M} / \mathrm{F} \\
\text { pair, } 1 / 3 \text { of parasites were } \\
\text { ovigerous. No breakdown } \\
\text { by specific host. }\end{array}$ & $\mathrm{OF}, \mathrm{F}$ & EX & $\begin{array}{l}\text { Nagato, } \\
\text { Yamaguchi, } \\
\text { Japan }\end{array}$ & OBS & $\mathrm{N}$ & 2012-2018 & $0-5 \mathrm{~m}$ & $\begin{array}{l}\text { Mazda et al., } \\
2019\end{array}$ \\
\hline $\begin{array}{l}\text { Aurelia limbata Brandt, } \\
1835\end{array}$ & $\begin{array}{l}\text { Hyperia galba Montagu, } \\
1813\end{array}$ & $\mathrm{~N} / \mathrm{A}$ & $\mathrm{F}, \mathrm{J}$ & $\mathrm{O}$ & Okirai Bay & $?$ & $\mathrm{~L}$ & 2009 Apr & $?$ & $\begin{array}{l}\text { Ohtsuka et al., } \\
2010\end{array}$ \\
\hline Aurelia sp. & $\begin{array}{l}\text { Nitokra medusaea } \\
\text { Humes, } 1953\end{array}$ & $\begin{array}{l}\text { Engage in excavation, } \\
\text { many epibionts on a single } \\
5 \text { ' medusa }\end{array}$ & $\begin{array}{l}\mathrm{F}, \mathrm{M}, \\
\mathrm{OF}\end{array}$ & EXC & $\begin{array}{l}\text { New } \\
\text { Hampshire } \\
\text { coast }\end{array}$ & $\mathrm{HC}$ & $\mathrm{L}$ & 1952 & NS & Humes, 1953 \\
\hline $\begin{array}{l}\text { Chrysaora colorata Russell, } \\
1964\end{array}$ & $\begin{array}{l}\text { Latreutes anoplonyx } \\
\text { Kemp, } 1914\end{array}$ & N/A & $?$ & $?$ & Kuwait Bay & TR & $?$ & $\begin{array}{l}1981 \text { Sept- } \\
1982 \text { Aug }\end{array}$ & $?$ & $\begin{array}{l}\text { Grabe \& Lees, } \\
1995\end{array}$ \\
\hline $\begin{array}{l}\text { Chrysaora colorata Russell, } \\
1964\end{array}$ & $\begin{array}{l}\text { Metacarcinus gracilis } \\
\text { Dana, } 1852\end{array}$ & $\begin{array}{l}\text { Dispersion, protection and } \\
\text { feeding, Mar-Aug }\end{array}$ & MG & $?$ & Monterey Bay & $?$ & $?$ & $\begin{array}{l}\text { 1991/1992 } \\
\text { Mar-Aug }\end{array}$ & $?$ & $\begin{array}{l}\text { Graham, } 1989 \\
\text { via Schiariti et } \\
\text { al., } 2012\end{array}$ \\
\hline $\begin{array}{l}\text { Chrysaora colorata Russell, } \\
1964\end{array}$ & $\begin{array}{l}\text { Metacarcinus gracilis } \\
\text { Dana, } 1852\end{array}$ & $\begin{array}{l}\text { Early stages of crabs on } \\
\text { medusae }\end{array}$ & $\mathrm{J}, \mathrm{MG}$ & $?$ & Califorina & $?$ & $?$ & $?$ & $?$ & $\begin{array}{l}\text { Wrobel \& Mills, } \\
1998 \text { via } \\
\text { Schiariti et al., } \\
2012\end{array}$ \\
\hline $\begin{array}{l}\text { Chrysaora fuscescens } \\
\text { Brandt, } 1835\end{array}$ & Cancer sp. & Crabs gain dispersion & $?$ & $?$ & Monterey Bay & ? & $?$ & $?$ & $?$ & $\begin{array}{l}\text { Graham, } 1994 \\
\text { via Schiariti et } \\
\text { al., } 2012\end{array}$ \\
\hline $\begin{array}{l}\text { Chrysaora fuscescens } \\
\text { Brandt, } 1835\end{array}$ & $\begin{array}{l}\text { Hyperoche medusarum } \\
\text { Kröyer, } 1838\end{array}$ & $\begin{array}{l}\text { Infestations occur in late } \\
\text { summer }\end{array}$ & $?$ & $?$ & $\begin{array}{l}\text { NE Pacific, } \\
\text { Oregon and } \\
\text { northern } \\
\text { California }\end{array}$ & ? & $?$ & $?$ & $?$ & Larson 1990 \\
\hline $\begin{array}{l}\text { Chrysaora fuscescens } \\
\text { Brandt, } 1835\end{array}$ & $\begin{array}{l}\text { Metacarcinus gracilis } \\
\text { Dana, } 1852\end{array}$ & N/A & $?$ & $?$ & $\begin{array}{l}\text { NE Pacific "off } \\
\text { California" }\end{array}$ & $?$ & $?$ & ? & $?$ & Larson 1990 \\
\hline $\begin{array}{l}\text { Chrysaora hysoscella } \\
\text { Linnaeus, } 1767\end{array}$ & $\begin{array}{l}\text { Hyperia galba Montagu, } \\
1813\end{array}$ & $\begin{array}{l}\text { Peak in Oct, reference for } \\
\text { mature medusae, consume } \\
\text { host gonad }\end{array}$ & $\mathrm{J}, \mathrm{A}$ & $\mathrm{O}$ & German Bight & $\mathrm{HC}+\mathrm{SC}$ & & $1984-1985$ & $?$ & Dittrich, 1988 \\
\hline $\begin{array}{l}\text { Chrysaora lactea } \\
\text { Eschscholtz, } 1829\end{array}$ & $\begin{array}{l}\text { Brachyscelus cf. } \\
\text { rapacoides Stephensen, } \\
1925\end{array}$ & Parasite & $\mathrm{L}, \mathrm{J}$ & $\mathrm{W}, \mathrm{O}$ & $\begin{array}{l}\text { Sao Sebastian } \\
\text { Channel }\end{array}$ & TR & $\mathrm{L}$ & 2015 Nov & $?$ & $\begin{array}{l}\text { Puente-Tapia et } \\
\text { al., } 2018\end{array}$ \\
\hline $\begin{array}{l}\text { Chrysaora lactea } \\
\text { Eschscholtz, } 1829\end{array}$ & $\begin{array}{l}\text { Cymothoa catarinensis } \\
\text { Thatcher, Loyola e Silva, } \\
\text { Jost \& Souza-Conceiçao, } \\
2003\end{array}$ & N/A & $?$ & EX & $\begin{array}{l}\text { Guaratuba, } \\
\text { Paraná e Baía } \\
\text { Norte, } \\
\text { Florianópolis, } \\
\text { Santa Catarina }\end{array}$ & TR & $\mathrm{L}$ & $\begin{array}{l}2003+ \\
2005, \text { Nov } \\
+ \text { May }\end{array}$ & $8-14 \mathrm{~m}$ & $\begin{array}{l}\text { Nogueira Junior } \\
\& \text { Silva, } 2005\end{array}$ \\
\hline
\end{tabular}




\begin{tabular}{|c|c|c|c|c|c|c|c|c|c|c|}
\hline $\begin{array}{l}\text { Chrysaora lactea } \\
\text { Eschscholtz, } 1829\end{array}$ & Periclimenes sp. & $\begin{array}{l}\text { Facultative commensal, } \\
\text { feeding on mucus, large } \\
\text { proportion ovigerous } \\
\text { females }\end{array}$ & $\begin{array}{l}\mathrm{OF}, \mathrm{A}, \\
\mathrm{J}\end{array}$ & SUM & São Paulo state & $\mathrm{HC}$ & $?$ & $\begin{array}{l}1999-2002 \\
+2006 \mathrm{Jul}\end{array}$ & NS & $\begin{array}{l}\text { Martinelli-Filho } \\
\text { et al., } 2008\end{array}$ \\
\hline $\begin{array}{l}\text { Chrysaora lactea } \\
\text { Eschscholtz, } 1829\end{array}$ & $\begin{array}{l}\text { Synidotea marplatensis } \\
\text { Giambiagi, } 1922\end{array}$ & $\mathrm{~N} / \mathrm{A}$ & $?$ & SUM & $\begin{array}{l}\text { Guaratuba, } \\
\text { Paraná e Barra } \\
\text { do Saí, Santa } \\
\text { Catarina, }\end{array}$ & $\mathrm{TR}$ & $\mathrm{L}$ & $\begin{array}{l}\text { 2003-2004 } \\
\text { Aug-Dec }\end{array}$ & $8-14 \mathrm{~m}$ & $\begin{array}{l}\text { Nogueira Junior } \\
\text { \& E Silva, } 2005\end{array}$ \\
\hline $\begin{array}{l}\text { Chrysaora melanaster } \\
\text { Brandt, } 1835\end{array}$ & $\begin{array}{l}\text { Hyperia galba Montagu, } \\
1813\end{array}$ & N/A & $\mathrm{J}$ & SUM, O & $\begin{array}{l}\text { Takehara City } \\
\left(3418^{\prime} \mathrm{N}, 132\right. \\
\left.55^{\prime} \mathrm{E}\right)\end{array}$ & $?$ & $\mathrm{~L}$ & $\begin{array}{l}2009 \text { Apr }+ \\
\text { Jun }\end{array}$ & $?$ & $\begin{array}{l}\text { Ohtsuka et al., } \\
2012\end{array}$ \\
\hline $\begin{array}{l}\text { Chrysaora pacifica Goette, } \\
1886\end{array}$ & $\begin{array}{l}\text { Oxycephalus } \\
\text { clausi Bovallius, } 1887\end{array}$ & $\begin{array}{l}\text { February to May, } 97.6 \% \\
\text { female, largely one female } \\
\text { per host, occasionally M/F } \\
\text { pair, } 1 / 3 \text { of parasites were } \\
\text { ovigerous. No breakdown } \\
\text { by specific host. }\end{array}$ & $\mathrm{OF}, \mathrm{F}$ & EX & $\begin{array}{l}\text { Nagato, } \\
\text { Yamaguchi, } \\
\text { Japan }\end{array}$ & OBS & $\mathrm{L}$ & $2012-2018$ & $0-5 \mathrm{~m}$ & $\begin{array}{l}\text { Mazda et al., } \\
2019\end{array}$ \\
\hline $\begin{array}{l}\text { Chrysaora plocamia Lesson, } \\
1830\end{array}$ & $\begin{array}{l}\text { Hyperia curticephala } \\
\text { Vinogradov \& } \\
\text { Semenova, } 1985\end{array}$ & $\begin{array}{l}\text { Mean 0f } 174.4 \\
\text { amphipods/host, } 79 \% \\
\text { female, ingested mesoglea }\end{array}$ & $\begin{array}{l}\text { M, F, } \\
\text { OF }\end{array}$ & $\mathrm{W}$ & Mejillones Bay & $\mathrm{SC}$ & $\mathrm{N}$ & $2005 \mathrm{Feb}$ & NS & $\begin{array}{l}\text { Oliva et al., } \\
2010\end{array}$ \\
\hline $\begin{array}{l}\text { Chrysaora quinquecirrha } \\
\text { Desor, } 1848\end{array}$ & $\begin{array}{l}\text { Callinectes sapidus } \\
\text { Rathbun, } 1896\end{array}$ & Not feeding on medusa & $? ?$ & EX & $\begin{array}{l}\text { Mississippi } \\
\text { sound }\end{array}$ & $\mathrm{HC}$ & $\mathrm{L}$ & 1968 Aug & NS & $\begin{array}{l}\text { Phillips et al., } \\
1969\end{array}$ \\
\hline $\begin{array}{l}\text { Chrysaora quinquecirrha } \\
\text { Desor, } 1848\end{array}$ & $\begin{array}{l}\text { Libinia dubia } \mathrm{H} \text {. Milne } \\
\text { Edwards, } 1834\end{array}$ & $\begin{array}{l}\text { Lower incidence rate near } \\
\text { surface than bottom trawls, } \\
\text { actively feeding on } \\
\text { medusae }\end{array}$ & $? ?$ & $\mathrm{~B}, \mathrm{O}$ & $\begin{array}{l}\text { Mississippi } \\
\text { sound }\end{array}$ & MULTI & $\mathrm{N}$ & 1968 Aug & NS & $\begin{array}{l}\text { Phillips et al., } \\
1969\end{array}$ \\
\hline $\begin{array}{l}\text { Chrysaora quinquecirrha } \\
\text { Desor, } 1848\end{array}$ & $\begin{array}{l}\text { Pseudomacrochiron } \\
\text { stocki Sars, } 1909\end{array}$ & $\begin{array}{l}12 \text { specimens from } 10 \\
\text { hosts }\end{array}$ & $\mathrm{F}, \mathrm{M}$ & $?$ & Madras Marina & $\mathrm{HC}$ & $\mathrm{N}$ & 1967, Oct & $?$ & Reddiah, 1969 \\
\hline Chrysaora sp. & $\begin{array}{l}\text { Cancer sp. cf. } \\
\text { antennarius* }\end{array}$ & $\mathrm{N} / \mathrm{A}$ & $\mathrm{J}, \mathrm{MG}$ & $?$ & $\begin{array}{l}\text { Southern } \\
\text { California } \\
\text { Bight }\end{array}$ & $\mathrm{HC}$ & $\mathrm{N}$ & $\begin{array}{l}1989 \text { Jul- } \\
\text { Sep }\end{array}$ & NS & $\begin{array}{l}\text { Martin \& Kuck, } \\
1991\end{array}$ \\
\hline Chrysaora sp. & $\begin{array}{l}\text { Hyperia medusarum } \\
\text { Müller, } 1776\end{array}$ & $\mathrm{~N} / \mathrm{A}$ & $\mathrm{F}$ & $?$ & $\begin{array}{l}\text { Southern } \\
\text { California } \\
\text { Bight }\end{array}$ & $\mathrm{HC}$ & $\mathrm{L}$ & $\begin{array}{l}\text { 1989. Jul- } \\
\text { Sep }\end{array}$ & NS & $\begin{array}{l}\text { Martin \& Kuck, } \\
1991\end{array}$ \\
\hline Chrysaora sp. & $\begin{array}{l}\text { Metamysidopsis elongata } \\
\text { Holmes, } 1900\end{array}$ & N/A & M & ? & $\begin{array}{l}\text { Southern } \\
\text { California } \\
\text { Bight }\end{array}$ & $\mathrm{HC}$ & $\mathrm{L}$ & $\begin{array}{l}\text { 1989. Jul- } \\
\text { Sep }\end{array}$ & NS & $\begin{array}{l}\text { Martin \& Kuck, } \\
1991\end{array}$ \\
\hline Chrysaora sp. & $\begin{array}{l}\text { Mysidopsis cathengelae } \\
\text { Gleye, } 1982\end{array}$ & N/A & M & $?$ & $\begin{array}{l}\text { Southern } \\
\text { California } \\
\text { Bight }\end{array}$ & $\mathrm{HC}$ & $\mathrm{L}$ & $\begin{array}{l}\text { 1989. Jul- } \\
\text { Sep }\end{array}$ & NS & $\begin{array}{l}\text { Martin \& Kuck, } \\
1991\end{array}$ \\
\hline $\begin{array}{l}\text { Cyanea capillata Linnaeus, } \\
1758\end{array}$ & $\begin{array}{l}\text { Alepas pacifica Pilsbry, } \\
1907\end{array}$ & $\begin{array}{l}\text { Seven barnacles from } \\
14.5-37 \mathrm{~mm} \text { in length on } \\
\text { the exumbrella and } \\
\text { umbrellar Margin. }\end{array}$ & $?$ & MA, EX & $\begin{array}{l}\text { Marion Bay, } \\
\text { Tazmania }\end{array}$ & $?$ & $\mathrm{~L}$ & 1985 & ? & $\begin{array}{l}\text { Liu \& Ren, } \\
1985 \text { via Pagès, } \\
2000\end{array}$ \\
\hline
\end{tabular}




\begin{tabular}{|c|c|c|c|c|c|c|c|c|c|c|}
\hline $\begin{array}{l}\text { Cyanea capillata Linnaeus, } \\
1758\end{array}$ & $\begin{array}{l}\text { Hyperia galba Montagu, } \\
1813\end{array}$ & $\begin{array}{l}\text { Inverted positioning, } \\
\text { plentiful in the spring }\end{array}$ & $\begin{array}{l}\text { A \& J } \\
\& \text { OF }\end{array}$ & MA, EX & $\begin{array}{l}\text { Narragansett } \\
\text { Marine } \\
\text { Laboratory }\end{array}$ & $\mathrm{HC}$ & $\mathrm{N}$ & $\begin{array}{l}1954 \text { Sep - } \\
1955 \text { Aug }\end{array}$ & NS & $\begin{array}{l}\text { Bowman et al., } \\
1963\end{array}$ \\
\hline $\begin{array}{l}\text { Cyanea capillata Linnaeus, } \\
1758\end{array}$ & $\begin{array}{l}\text { Hyperia galba Montagu, } \\
1813\end{array}$ & $\mathrm{~N} / \mathrm{A}$ & $\begin{array}{l}\text { A \& J } \\
\& \text { OF }\end{array}$ & $?$ & Niantic River & TR & $\mathrm{N}$ & $\begin{array}{l}\text { 1960, May } \\
+ \text { Jun }\end{array}$ & NS & $\begin{array}{l}\text { Bowman et al., } \\
1963\end{array}$ \\
\hline $\begin{array}{l}\text { Cyanea capillata Linnaeus, } \\
1758\end{array}$ & $\begin{array}{l}\text { Hyperia galba Montagu, } \\
1813\end{array}$ & $\begin{array}{l}\text { Peak in Oct, reference for } \\
\text { mature medusae, consume } \\
\text { host gonad }\end{array}$ & $\mathrm{J}, \mathrm{A}$ & $\mathrm{O}$ & German Bight & $\mathrm{HC}+\mathrm{SC}$ & & 1984-1985 & $?$ & Dittrich, 1988 \\
\hline $\begin{array}{l}\text { Cyanea capillata Linnaeus, } \\
1758\end{array}$ & $\begin{array}{l}\text { Hyperoche medusarum } \\
\text { Kröyer, } 1838\end{array}$ & Single specimen in May & $\mathrm{J}$ & ? & Niantic River & $\mathrm{HC}$ & $\mathrm{L}$ & $\begin{array}{l}\text { 1960, May } \\
+ \text { Jun }\end{array}$ & NS & $\begin{array}{l}\text { Bowman et al., } \\
1963\end{array}$ \\
\hline $\begin{array}{l}\text { Cyanea capillata Linnaeus, } \\
1758\end{array}$ & $\begin{array}{l}\text { Themisto australis } \\
\text { Stebbing, } 1888\end{array}$ & $\begin{array}{l}\text { Cradle positioning, no bell } \\
\text { damage, all sampled } \\
\text { epibionts submature } \\
\text { females }\end{array}$ & $\mathrm{JF}$ & EX & $\begin{array}{l}\text { Rye Pier } \\
\left(38^{\circ} 23^{\prime} \mathrm{S}\right. \\
\left.144^{\circ} 50^{\prime} \mathrm{E}\right)\end{array}$ & $\mathrm{HC}$ & $\mathrm{N}$ & $\begin{array}{l}\text { 1995, Jun- } \\
\text { Oct }\end{array}$ & NS & $\begin{array}{l}\text { Condon \& } \\
\text { Norman, } 1999\end{array}$ \\
\hline $\begin{array}{l}\text { Cyanea nozakii Kishinouye, } \\
1891\end{array}$ & $\begin{array}{l}\text { Alepas pacifica Pilsbry, } \\
1907\end{array}$ & $\begin{array}{l}\text { Relationship } \\
\text { uncharacterized except to } \\
\text { note epibiont presence on } \\
\text { umbrella and oral arms. }\end{array}$ & $?$ & $\mathrm{~B}, \mathrm{O}$ & Japanese Coast & $?$ & $?$ & $?$ & $?$ & $\begin{array}{l}\text { Hiro } 1938 \text { via } \\
\text { Pagès, } 2000\end{array}$ \\
\hline $\begin{array}{l}\text { Cyanea nozakii Kishinouye, } \\
1891\end{array}$ & $\begin{array}{l}\text { Alepas pacifica Pilsbry, } \\
1907\end{array}$ & $\begin{array}{l}3 \text { barnacles on the } \\
\text { umbrella up to a length of } \\
130 \mathrm{~mm}\end{array}$ & $?$ & EX & Shanghai & $?$ & $?$ & 1946 & $?$ & $\begin{array}{l}\text { Tubb, } 1946 \text { via } \\
\text { Pagès, } 2000\end{array}$ \\
\hline $\begin{array}{l}\text { Cyanea nozakii Kishinouye, } \\
1891\end{array}$ & $\begin{array}{l}\text { Alepas pacifica Pilsbry, } \\
1907\end{array}$ & Substrate & $\begin{array}{l}\text { M, F, } \\
\text { OF }\end{array}$ & B & $\begin{array}{l}\text { Western Coast } \\
\text { of Japan }\end{array}$ & $\mathrm{HC}$ & $\mathrm{L}$ & 2005-2009 & $?$ & $\begin{array}{l}\text { Yusa et al., } \\
2015\end{array}$ \\
\hline $\begin{array}{l}\text { Deepstaria enigmatica } \\
\text { Russell, } 1967\end{array}$ & Anuropidae gn sp. & $\begin{array}{l}\text { Two anuropids close to the } \\
\text { oral arm base on one } \\
\text { medusa }\end{array}$ & $?$ & O, SUM & Mutsu Bay & ROV & $\mathrm{L}$ & $\begin{array}{l}2002 \\
\text { Apr/May }\end{array}$ & $669 \mathrm{~m}$ & $\begin{array}{l}\text { Lindsay et al., } \\
2004\end{array}$ \\
\hline $\begin{array}{l}\text { Deepstaria enigmatica } \\
\text { Russell, } 1967\end{array}$ & Anuropus sp. & Parasitic & $?$ & SUM & $\begin{array}{l}\text { San Diego } \\
\text { Trough }\end{array}$ & ROV & $\mathrm{L}$ & 1966 Oct & $723 \mathrm{~m}$ & $\begin{array}{l}\text { Barham \& } \\
\text { Pickwell, } 1969\end{array}$ \\
\hline $\begin{array}{l}\text { Diplulmaris malayensis } \\
\text { Stiasny, } 1935\end{array}$ & $\begin{array}{l}\text { Alepas pacifica Pilsbry, } \\
1907\end{array}$ & $\begin{array}{l}15 \text { barnacles found on } 10 \\
\text { hosts, mostly attached to } \\
\text { the subumbrellar margins. } \\
1 \text { to } 3 \text { epibionts per host. } \\
11 \text { were oriented towards } \\
\text { the GVC opening and oral } \\
\text { arms of the host. } \\
\text { Hypothesized consumption } \\
\text { of gonadal tissue by this } \\
\text { epibiont. }\end{array}$ & $?$ & MA & $\begin{array}{l}3429.4^{\prime} \mathrm{N}, 138 \\
32.6^{\prime} \mathrm{E}\end{array}$ & TR & $\mathrm{N}$ & 1981 Jun & NS & Pagès, 2000 \\
\hline $\begin{array}{l}\text { Pelagia noctiluca Forsskål, } \\
1775\end{array}$ & $\begin{array}{l}\text { Alepas pacifica Pilsbry, } \\
1907\end{array}$ & $\begin{array}{l}\text { Over } 100 \text { barnacles on the } \\
\text { umbrellar and oral arm } \\
\text { regions of an unknown } \\
\text { number of medusae. }\end{array}$ & $?$ & $\mathrm{~B}, \mathrm{O}$ & Japanese Coast & ? & $?$ & $?$ & $?$ & $\begin{array}{l}\text { Hiro } 1937 \text { via } \\
\text { Pagès, } 2000\end{array}$ \\
\hline $\begin{array}{l}\text { Pelagia noctiluca Forsskål, } \\
1775\end{array}$ & $\begin{array}{l}\text { Alepas pacifica Pilsbry, } \\
1907\end{array}$ & N/A & $?$ & SUM & $39 \mathrm{~N}, 52 \mathrm{~W}$ & $?$ & $?$ & ? & ? & $\begin{array}{l}\text { Madin unpubl } \\
\text { data via Pagès, } \\
2000\end{array}$ \\
\hline
\end{tabular}


Pelagia noctiluca Forsskål, 1775

Pelagia noctiluca Forsskål, 1775

Pelagia noctiluca Forsskål, 1775

Pelagia noctiluca Forsskål, 1775

Pelagia panopyra Péron \& Lesueur, 1810

Phacellophora camtschatica Brandt, 1835

Phacellophora camtschatica Brandt, 1835

Phacellophora camtschatica Brandt, 1835

Poralia rufescens

Vanhöffen, 1902

Poralia rufescens

Vanhöffen, 1902

Poralia rufescens

Vanhöffen, 1902
Alepas pacifica Pilsbry,

1907

Anelasma sp.

Oxycephalus

clausi Bovallius, 1887

Thamneus rostratus

Bovallius, 1887

Ibacus sp.

(2)

Alepas pacifica Pilsbry, 1907

Hyperia medusarum Müller, 1776

Metacarcinus gracilis Dana, 1852

Lanceola clausi

Bovallius, 1885

Lysianassinae gn sp.

Pseudocallisoma coecum Holmes, 1908
One barnacle $20 \mathrm{~mm}$ long, present on an oral arm

Medusae up to $60 \mathrm{~mm}$ in diameter, unknown

epibiont number, size and position.

February to May, $97.6 \%$

female, largely one female

per host, occasionally $\mathrm{M} / \mathrm{F}$ pair, $1 / 3$ of parasites were ovigerous. No breakdown by specific host.

Relatively rare species

Each medusa had a

phyllosoma larva ftrmly

attached to the bell

surface. The larvae were

difficult to remove withou

injuring them, considered

parasitoid relationship.

$25-5.1 \mathrm{~cm}$ long barnacles on a $50 \mathrm{~mm}$

Parasitoid, May to Sept,

100 s of amphipods, $100 \%$

of hosts had infestation in July

Association appears in

May, once bell widths of

hosts begin to exceed 3

$\mathrm{cm}$, peaks in June/July,

few after mid-Oct

\section{N/A}

Attached at base of oral arms, 1-6 per medusa

A \& J SUM

Gulf of

California

PL EX

Sydney Harbor ？

Tasman sea

$? \quad ?$

$\mathrm{M} \& \mathrm{~F} \quad \mathrm{O}$

$\& \mathrm{~J}$

Only juvenile specimens

F,

M, J SUM

Suruga Bay

O, SUM Japan Trench

ROV

Japan Trench

ROV

$?$

?

(0)

(1)

Gasca \&

Haddock, 2004

Thomas, 1963
Utinomi, 1958

via Pagès, 2000

Kishinouye,

1902 via Pagès,

Mazda et al.,

\section{$\underline{\text { Hydrozoa }}$}




\begin{tabular}{|c|c|c|c|c|c|c|c|c|c|c|}
\hline \multicolumn{11}{|l|}{ Anthoathecata } \\
\hline $\begin{array}{l}\text { Bythotiara depressa } \\
\text { Naumov , } 1960\end{array}$ & Scina sp. & N/A & $?$ & $?$ & $\begin{array}{l}\text { Gulf of } \\
\text { California }\end{array}$ & ROV & $\mathrm{L}$ & 2007 Dec & $494 \mathrm{~m}$ & $\begin{array}{l}\text { Gasca et al., } \\
2015\end{array}$ \\
\hline Bythotiara sp. & $\begin{array}{l}\text { Mimonectes sphaericus } \\
\text { Bovallius, } 1885\end{array}$ & N/A & $?$ & $\mathrm{~B}$ & $\begin{array}{l}\text { Gulf of } \\
\text { California }\end{array}$ & ROV & $\mathrm{L}$ & 2006 May & $690 \mathrm{~m}$ & $\begin{array}{l}\text { Gasca et al., } \\
2015\end{array}$ \\
\hline $\begin{array}{l}\text { Leuckartiara octona } \\
\text { Fleming, } 1823\end{array}$ & $\begin{array}{l}\text { Hyperia medusarum } \\
\text { Müller, } 1776\end{array}$ & N/A & $\mathrm{JM}$ & $?$ & $\begin{array}{l}\text { Gulf of } \\
\text { California }\end{array}$ & $\mathrm{SC}$ & $\mathrm{L}$ & 2006 Sep & $<30 \mathrm{~m}$ & $\begin{array}{l}\text { Gasca et al., } \\
2015\end{array}$ \\
\hline $\begin{array}{l}\text { Leuckartiara zacae Bigelow, } \\
1940\end{array}$ & $\begin{array}{l}\text { Hyperia medusarum } \\
\text { Müller, } 1776\end{array}$ & N/A & $\mathrm{F}, \mathrm{J}$ & $?$ & $\begin{array}{l}\text { Monterey } \\
\text { California }\end{array}$ & $\mathrm{SC}$ & $\mathrm{L}$ & 2004 May & $10 \mathrm{~m}$ & $\begin{array}{l}\text { Gasca et al., } \\
2007\end{array}$ \\
\hline $\begin{array}{l}\text { Leuckartiara zacae Bigelow, } \\
1940\end{array}$ & $\begin{array}{l}\text { Lestrigonus } \\
\text { schizogeneios Stebbing, } \\
1888\end{array}$ & N/A & JF & $?$ & $\begin{array}{l}\text { Monterey } \\
\text { California }\end{array}$ & $\mathrm{SC}$ & $\mathrm{L}$ & 2004 May & $5-15 m$ & $\begin{array}{l}\text { Gasca et al., } \\
2007\end{array}$ \\
\hline Neoturris sp.. & $\begin{array}{l}\text { Hyperia medusarum } \\
\text { Müller, } 1776\end{array}$ & N/A & $\mathrm{OF}, \mathrm{J}$ & $?$ & $\begin{array}{l}\text { Monterey } \\
\text { California }\end{array}$ & ROV & $\mathrm{L}$ & 2004 May & $237 \mathrm{~m}$ & $\begin{array}{l}\text { Gasca et al., } \\
2007\end{array}$ \\
\hline \multicolumn{11}{|l|}{ Leptothecata } \\
\hline $\begin{array}{l}\text { Aequorea coerulescens } \\
\text { Brandt, } 1835\end{array}$ & Brachyscelidae gn sp. & N/A & $\mathrm{J}$ & $?$ & $\begin{array}{l}\text { Gulf of } \\
\text { California }\end{array}$ & $\mathrm{SC}$ & $\mathrm{L}$ & 2003 Mar & $10 \mathrm{~m}$ & $\begin{array}{l}\text { Gasca \& } \\
\text { Haddock, } 2004\end{array}$ \\
\hline $\begin{array}{l}\text { Aequorea coerulescens } \\
\text { Brandt, } 1835\end{array}$ & $\begin{array}{l}\text { Brachyscelus crusculum } \\
\text { Spence Bate, } 1861\end{array}$ & N/A & $\begin{array}{l}\mathrm{JM}, \mathrm{A} \\
\& \mathrm{OF}\end{array}$ & EX & $\begin{array}{l}\text { Gulf of } \\
\text { California }\end{array}$ & $\mathrm{SC}$ & $\mathrm{L}$ & 2003 Mar & $10-15 \mathrm{~m}$ & $\begin{array}{l}\text { Gasca \& } \\
\text { Haddock, } 2004\end{array}$ \\
\hline $\begin{array}{l}\text { Aequorea coerulescens } \\
\text { Brandt, } 1835\end{array}$ & $\begin{array}{l}\text { Ibacus ciliatus von } \\
\text { Siebold, } 1824\end{array}$ & N/A & PL & $?$ & $\begin{array}{l}\text { Yamaguchi, } \\
\text { Japan }\end{array}$ & $?$ & $?$ & $?$ & $?$ & $\begin{array}{l}\text { Wakabayashi et } \\
\text { al., } 2017 \text { via } \\
\text { Wakabayashi et } \\
\text { al., } 2019\end{array}$ \\
\hline $\begin{array}{l}\text { Aequorea coerulescens } \\
\text { Brandt, } 1835\end{array}$ & $\begin{array}{l}\text { Oxycephalus } \\
\text { clausi Bovallius, } 1887\end{array}$ & $\begin{array}{l}\text { February to May, } 97.6 \% \\
\text { female, largely one female } \\
\text { per host, occasionally } \mathrm{M} / \mathrm{F} \\
\text { pair, } 1 / 3 \text { of parasites were } \\
\text { ovigerous. No account } \\
\text { breakdown by specific } \\
\text { host. }\end{array}$ & $\mathrm{OF}, \mathrm{F}$ & EX & $\begin{array}{l}\text { Nagato, } \\
\text { Yamaguchi, } \\
\text { Japan }\end{array}$ & OBS & $\mathrm{N}$ & $2012-2018$ & $0-5 \mathrm{~m}$ & $\begin{array}{l}\text { Mazda et al. } \\
2019\end{array}$ \\
\hline $\begin{array}{l}\text { Aequorea coerulescens } \\
\text { Brandt, } 1835\end{array}$ & $\begin{array}{l}\text { Sapphirina } \\
\text { nigromaculata Claus, } \\
1863\end{array}$ & N/A & $?$ & MA & $\begin{array}{l}\text { Gulf of } \\
\text { California }\end{array}$ & $\mathrm{SC}$ & $\mathrm{L}$ & 2003 Mar & $10 \mathrm{~m}$ & $\begin{array}{l}\text { Gasca \& } \\
\text { Haddock, } 2004\end{array}$ \\
\hline $\begin{array}{l}\text { Aequorea coerulescens } \\
\text { Brandt, } 1835\end{array}$ & $\begin{array}{l}\text { Thamneus rostratus } \\
\text { Bovallius, } 1887\end{array}$ & $\begin{array}{l}\text { Relatively rare amphipod } \\
\text { species }\end{array}$ & $\mathrm{J}$ & B & $\begin{array}{l}\text { Gulf of } \\
\text { California }\end{array}$ & $\mathrm{SC}$ & $\mathrm{L}$ & 2003 Mar & $10 \mathrm{~m}$ & $\begin{array}{l}\text { Gasca \& } \\
\text { Haddock, } 2004\end{array}$ \\
\hline $\begin{array}{l}\text { Aequorea eurodina* Péron } \\
\& \text { Lesueur, } 1810\end{array}$ & $\begin{array}{l}\text { Hyperia gaudichaudii } \mathrm{H} \text {. } \\
\text { Milne Edwards, } 1840\end{array}$ & 2 attached to one medusa & $?$ & $?$ & $\begin{array}{l}38^{\circ} 05^{\prime} 17^{\prime \prime}- \\
38^{\circ} 17^{\prime} 1 " \mathrm{~S}, \\
144^{\circ} 36^{\prime} 54^{\prime \prime}- \\
\left.144^{\circ} 43^{\prime} 58^{\prime \prime} \mathrm{E}\right)\end{array}$ & $\mathrm{HC}$ & $\mathrm{L}$ & $\begin{array}{l}2009 \mathrm{Sep}+ \\
2012 \mathrm{Feb}\end{array}$ & NS & Browne, 2015 \\
\hline $\begin{array}{l}\text { Aequorea macrodactyla } \\
\text { Brandt, } 1835\end{array}$ & $\begin{array}{l}\text { Ibacus novemdentatus } \\
\text { Gibbes, } 1850\end{array}$ & N/A & PL & $?$ & $\begin{array}{l}\text { Nagasaki, } \\
\text { Japan }\end{array}$ & $?$ & $?$ & $?$ & $?$ & $\begin{array}{l}\text { Shojima, } 1973 \\
\text { via } \\
\text { Wakabayashi et }\end{array}$ \\
\hline
\end{tabular}




\begin{tabular}{|c|c|c|c|c|c|c|c|c|c|c|}
\hline $\begin{array}{l}\text { Aequorea victoria Murbach } \\
\text { \& Shearer, } 1902\end{array}$ & $\begin{array}{l}\text { Ibacus ciliatus von } \\
\text { Siebold, } 1824\end{array}$ & $\begin{array}{l}\text { Riding small medusae, } \\
\text { pierced exumbrella with } \\
\text { pereiopods, attached to a } \\
\text { salp as well, parasitoid } \\
\text { relationship hypothesized. }\end{array}$ & PL & EX & Japan & OBS & $\mathrm{L}$ & $?$ & $?$ & $\begin{array}{l}\text { Wakabayashi et } \\
\text { al., } 2019\end{array}$ \\
\hline $\begin{array}{l}\text { Chromatonema } \\
\text { erythrogonon, Bigelow, } \\
1909\end{array}$ & $\begin{array}{l}\text { Hyperoche medusarum } \\
\text { Kröyer, } 1838\end{array}$ & N/A & OF & $?$ & $\begin{array}{l}\text { Gulf of } \\
\text { California }\end{array}$ & ROV & $\mathrm{L}$ & 2003 Mar & $1100 \mathrm{~m}$ & $\begin{array}{l}\text { Gasca \& } \\
\text { Haddock, } 2004\end{array}$ \\
\hline $\begin{array}{l}\text { Clytia hemisphaerica } \\
\text { Linnaeus, } 1767\end{array}$ & $\begin{array}{l}\text { Eduarctus martensii } \\
\text { Pfeffer, } 1881\end{array}$ & N/A & PL & $?$ & $\begin{array}{l}\text { Yamaguchi, } \\
\text { Japan }\end{array}$ & $?$ & $?$ & $?$ & $?$ & $\begin{array}{l}\text { Wakabayashi et } \\
\text { al, } 2017 \text { via } \\
\text { Wakabayashi et } \\
\text { al, } 2019\end{array}$ \\
\hline Clytia sp. & $\begin{array}{l}\text { Metopa borealis G. O. } \\
\text { Sars, } 1883\end{array}$ & $\begin{array}{l}\text { Association from Oct to } \\
\text { March, epibionts passed } \\
\text { between medusae. }\end{array}$ & $?$ & $\mathrm{~B}, \mathrm{O}$ & West Scotland & $?$ & $\mathrm{~N}$ & Oct - Mar & $?$ & $\begin{array}{l}\text { Elmhirst, } 1925 \\
\text { via Vader, } 1972\end{array}$ \\
\hline $\begin{array}{l}\text { Eutonina indicans Romanes, } \\
1876\end{array}$ & $\begin{array}{l}\text { Tryphana malmii Boeck, } \\
1871\end{array}$ & N/A & $?$ & $?$ & $\begin{array}{l}\text { Gulf of } \\
\text { California }\end{array}$ & ROV & $\mathrm{L}$ & 2006 May & $202 \mathrm{~m}$ & $\begin{array}{l}\text { Gasca et al., } \\
2015\end{array}$ \\
\hline $\begin{array}{l}\text { Mitrocoma cellularia } \\
\text { Agassiz, } 1862\end{array}$ & $\begin{array}{l}\text { Hyperoche medusarum } \\
\text { Kröyer, } 1838\end{array}$ & N/A & $\mathrm{OF}, \mathrm{J}$ & W & $\begin{array}{l}\text { Monterey } \\
\text { California }\end{array}$ & $\mathrm{SC}$ & $\mathrm{L}$ & 2004 May & $10 \mathrm{~m}$ & $\begin{array}{l}\text { Gasca et al., } \\
2007\end{array}$ \\
\hline $\begin{array}{l}\text { Mitrocoma cellularia } \\
\text { Agassiz, } 1862\end{array}$ & $\begin{array}{l}\text { Tryphana malmii Boeck, } \\
1871\end{array}$ & $\mathrm{~N} / \mathrm{A}$ & $\mathrm{JF}$ & & $\begin{array}{l}\text { Monterey } \\
\text { California }\end{array}$ & $\mathrm{SC}$ & $\mathrm{L}$ & 2004 May & $5-15 \mathrm{~m}$ & $\begin{array}{l}\text { Gasca et al., } \\
2007\end{array}$ \\
\hline Tima bairdii Johnston, 1833 & $\begin{array}{l}\text { Metopa alderi Spence } \\
\text { Bate, } 1857\end{array}$ & $\begin{array}{l}\text { Speculates year-round } \\
\text { relationship, mobile on } \\
\text { medusa, did not feed on } \\
\text { host tissue, fed on mucus }\end{array}$ & $\begin{array}{l}\mathrm{J} \& \mathrm{~A} \\
\& \mathrm{OF}\end{array}$ & $\begin{array}{l}\text { SUM, } \\
\mathrm{O}, \mathrm{B}, \mathrm{T}\end{array}$ & Bergen & $?$ & $\mathrm{~N}$ & $1970 \mathrm{Apr}$ & $?$ & Vader, 1972 \\
\hline Tima formosa Agassiz, 1862 & $\begin{array}{l}\text { Hyperoche medusarum } \\
\text { Kröyer, } 1838\end{array}$ & N/A & $\mathrm{JF}$ & $?$ & $\begin{array}{l}\text { Narragansett } \\
\text { Marine } \\
\text { Laboratory }\end{array}$ & $\mathrm{HC}$ & $\mathrm{L}$ & $\begin{array}{l}1954 \text { Sep - } \\
1957 \text { Aug }\end{array}$ & NS & $\begin{array}{l}\text { Bowman et al., } \\
1963\end{array}$ \\
\hline $\begin{array}{l}\text { Tima sp. } \\
\text { Limnomedusae }\end{array}$ & $\begin{array}{l}\text { Iulopis mirabilis } \\
\text { Bovallius, } 1887\end{array}$ & N/A & $\mathrm{J} \& \mathrm{~A}$ & $?$ & $\begin{array}{l}\text { Gulf of } \\
\text { California }\end{array}$ & $\mathrm{SC}$ & $\mathrm{L}$ & 2006 Sep & $<30 \mathrm{~m}$ & $\begin{array}{l}\text { Gasca et al., } \\
2015\end{array}$ \\
\hline $\begin{array}{l}\text { Liriope tetraphylla } \\
\text { Chamisso \& Eysenhardt, } \\
1821\end{array}$ & $\begin{array}{l}\text { Simorhynchotus } \\
\text { antennarius Claus, } 1871\end{array}$ & $\mathrm{~N} / \mathrm{A}$ & $0 \mathrm{~F}$ & $?$ & $\begin{array}{l}\text { Gulf of } \\
\text { California }\end{array}$ & $\mathrm{SC}$ & $\mathrm{L}$ & 2006 Jun & $<30 \mathrm{~m}$ & $\begin{array}{l}\text { Gasca et al., } \\
2015\end{array}$ \\
\hline $\begin{array}{l}\text { Liriope tetraphylla } \\
\text { Chamisso \& Eysenhardt, } \\
1821\end{array}$ & $\begin{array}{l}\text { Ibacus ciliatus von } \\
\text { Siebold, } 1824\end{array}$ & N/A & PL & $?$ & $\begin{array}{l}\text { Nagasaki, } \\
\text { Japan }\end{array}$ & $?$ & $?$ & $?$ & $?$ & $\begin{array}{l}\text { Shojima, } 1973 \\
\text { via } \\
\text { Wakabayashi } \\
2019\end{array}$ \\
\hline Liriope sp. & $\begin{array}{l}\text { Scyllarus chacei } \\
\text { Holthuis, } 1960\end{array}$ & $\begin{array}{l}30 \% \text { of phyllosoma } \\
\text { attached to at least one GZ } \\
\text { species, primarily } \\
\text { hydrozoa, parasitoid }\end{array}$ & PL & EX & $\begin{array}{l}\text { Northern Gulf } \\
\text { of Mexico }\end{array}$ & $\begin{array}{l}\text { OBS, } \\
\text { TR }\end{array}$ & $\mathrm{N}$ & 2015 Oct & $1-31 \mathrm{~m}$ & Greer et al. 2017 \\
\hline
\end{tabular}


relationship.

Olindias sambaquiensis Müller, 1861

Olindias sambaquiensi Müller, 1861

Brachyscelus cf. rapacoides Stephensen, 1925

Synidotea marplatensis

Giambiagi, 1922

Reduction in mouthpart of epibionts higher in females

N/A

/A

$\begin{array}{ll}\begin{array}{l}\text { Synidotea marplatensis } \\ \text { Giambiagi, } 1922\end{array} & \text { N/A } \\ & \\ & \\ \begin{array}{l}\text { Iulopis loveni Bovallius, } \\ 1887\end{array} & \text { N/A } \\ \begin{array}{l}\text { Iulopis mirabilis } \\ \text { Bovallius, 1887 } \\ \text { Lanceola pacifica }\end{array} & \text { N/A } \\ \begin{array}{l}\text { Stebbing, 1888 } \\ \text { Prohyperia shihi Gasca, } \\ \text { 2005 }\end{array} & \text { N/A } \\ \begin{array}{l}\text { Pseudolubbockia dilatata } \\ \text { Sars, 1909 }\end{array} & \begin{array}{l}\text { Refuge and mating, mating } \\ \text { pairs with long residence } \\ \text { time evident on more than } \\ \text { one occasion }\end{array} \\ \begin{array}{l}\text { Prohyperia shihi Gasca, } \\ \text { N/A }\end{array}\end{array}$

Pegantha laevis Bigelow, 1909

Solmissus incisa Fewkes,

1886

Solmissus incisa Fewkes,

1886

Solmissus incisa Fewkes,

1886

Solmissus incisa Fewkes,

1886

Solmissus sp.

Solmissus sp

Apolemia sp.

Apolemia sp.

Athorybia rosacea Forsskål,

1775
2005

Brachyscelus sp.

Thamneus rostratus

Bovallius, 1887

\section{N/A \\ N/A}

Tryphana malmii Boeck, N/A

1871

Tryphana malmii Boeck,

1871

Hyperia medusarum

Müller, 1776

Hyperia sp.

Megalanceoloides

Mimonectes loveni

Bovallius, 1885

Parascelus edwardsi

Claus, 1879

N/A

N/A

N/A

N/A

N/A

Relatively rare amphipod

species aequanime Gasca, 2017

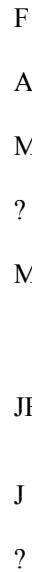

A ? California

California

Monterey

California

$\begin{array}{ll}\text { ? } & \text { California } \\ & \text { Calf of } \\ & \text { California }\end{array}$

M, F SUM Monterey

California

JF GVC Gulf of

California

Gulf of

California

Monterey

California

Monterey

California

Gulf of

California

Gulf of

California

Gulf of

California

$?$

Gulf of

California

Gulf of

California
Gulf of

California
TR

$2015 \mathrm{Nov}$

$8-14$

al., 2018

Nogueira Junior

\& E Silva, 2005

Aug-Dec

\begin{tabular}{|c|c|c|c|c|}
\hline ROV & $\mathrm{L}$ & 2007 Jan & $83 \mathrm{~m}$ & $\begin{array}{l}\text { Gasca et al., } \\
2015\end{array}$ \\
\hline ROV & $\mathrm{L}$ & 2006 Oct & $\begin{array}{l}1286- \\
1478 \mathrm{~m}\end{array}$ & $\begin{array}{l}\text { Gasca et al., } \\
2015\end{array}$ \\
\hline ROV & $\mathrm{L}$ & 2005 Apr & $1322 \mathrm{~m}$ & $\begin{array}{l}\text { Gasca et al., } \\
2007\end{array}$ \\
\hline ROV & $\mathrm{L}$ & 2007 Aug & $554 \mathrm{~m}$ & $\begin{array}{l}\text { Gasca et al., } \\
2015\end{array}$ \\
\hline ROV & $\mathrm{L}$ & 2004 May & $\begin{array}{l}\text { 606-1098 } \\
\mathrm{m}\end{array}$ & $\begin{array}{l}\text { Gasca et al., } \\
2007\end{array}$ \\
\hline
\end{tabular}

ROV

L

$2015 \mathrm{Ma}$

$926 \mathrm{~m}$

Gasca \&

Browne, 2018

ROV L 2006 May $497 \mathrm{~m} \quad$ Gasca et al.,

ROV

$\mathrm{L}$

$2005 \mathrm{Apr}$

$243 \mathrm{~m}$

2015

Gasca et al.,

2007

ROV

$\mathrm{L}$

2004 May

$458 \mathrm{~m}$

Gasca et al.,

2007

ROV

L

2006 May

$295 \mathrm{~m}$

Gasca et al.,

ROV

L

2006 Sep

$498 \mathrm{~m}$

2015

Gasca et al.

2015

ROV

L

2006 Sep

396-43

Gasca et al.,

ROV

L

2015 Mar

$2094 \mathrm{~m}$

2015

ROV

$2015 \mathrm{Ma}$

$2325-$

Browne, 2018

SC

L

2003 Mar
2589 m Growne, 2018

$10 \mathrm{~m} \quad$ Gasca \&

Gasca \& 2004 
Chelophyes appendiculata Eschscholtz, 1829

Diphyes bojani Eschscholtz, 825

Nectadamas diomedeae Bigelow, 1911

Nectadamas diomedeae Bigelow, 1911

Nectadamas diomedeae Bigelow, 1911

\section{Siphonophorae}

Muggiea sp.

Physophora hydrostatica Forsskål, 1775

Prayidae gn sp

Resomia ornicephala Pugh \& Haddock, 2010

Resomia ornicephala Pugh \& Haddock, 2010

Rosacea cymbiformis Delle Chiaje, 1830

Rosacea cymbiformis Delle Chiaje, 1830

Rosacea cymbiformis Delle Chiaje, 1830

Sulculeolaria quadrivalvis de Blainville, 1830
Paralycaea hoylei Stebbing, 1888

Lestrigonus bengalensis Giles, 1897

Mimonectes sphaericus Bovallius, 1885

Mimonectes sphaericus Bovallius, 1885

Mimonectes stephenseni Pirlot, 1929

Scyllarus chace Holthuis, 1960

$30 \%$ of phyllosoma attached to at least one GZ species, primarily

hydrozoa, parasitoid

relationship hypothesized.

Tryphana malmii Boeck, 187

Scyllaridae gn sp

Anapronoe reinhardti Stephensen, 1925

Tryphana malmii Boeck, 187

Brachyscelus crusculum Spence Bate, 1861

Eupronoe minuta Claus, 1879

Paraphronima gracilis

Claus, 1879

Simorhynchotus antennarius Claus, 1871

N/A
AttactA
N/A
N/A
N/A
N/A
N/A

JF

F, JF W

California

Cabo Frio (RJ) TR

and the Santa

(SC)

M

Monterey

Gulf of

California

Monterey

California

PL EX

Northern Gulf

of Mexico
Catarina Island

SC

ROV

ROV

ROV

ROV

(1)

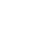

L 200

2004 May

1980, 17-23 ?

Jan

$\begin{array}{rrl}2005 \text { Apr } & 1082 \mathrm{~m} & \begin{array}{l}\text { Gasca et al., } \\ 2007\end{array} \\ 2006 \text { May } & 1344 \mathrm{~m} & \begin{array}{l}\text { Gasca et al., } \\ 2015\end{array} \\ & & \begin{array}{l}\text { Gasca et al., } \\ 2007\end{array}\end{array}$

2015 Oct

1-31 m

Greer et al. 2017

California

Gran Canaria,

Spain

Gulf of

California

Gulf of

California

$\begin{array}{ll}\text { OF, A, } \quad ? \quad \begin{array}{l}\text { Gulf of } \\ \text { J }\end{array} & \text { California }\end{array}$

JF GVC

Gulf of
California

JF ?

Gulf of

California

Gulf of

California

Cabo Frio (RJ)

and the Santa

Catarina Island

(SC)

\section{Trachymedusae}




\begin{tabular}{|c|c|c|c|c|c|c|c|c|c|c|}
\hline $\begin{array}{l}\text { Haliscera bigelowi Kramp, } \\
1947\end{array}$ & $\begin{array}{l}\text { Hyperia medusarum } \\
\text { Müller, } 1776\end{array}$ & N/A & $\mathrm{J}$ & $?$ & $\begin{array}{l}\text { Gulf of } \\
\text { California }\end{array}$ & $\mathrm{SC}$ & $\mathrm{L}$ & $2006 \mathrm{Sep}$ & $<30 \mathrm{~m}$ & $\begin{array}{l}\text { Gasca et al., } \\
2015\end{array}$ \\
\hline $\begin{array}{l}\text { Haliscera bigelowi Kramp, } \\
1947\end{array}$ & $\begin{array}{l}\text { Scina spinosa } \text { Vosseler, } \\
1901\end{array}$ & N/A & M & & $\begin{array}{l}\text { Monterey } \\
\text { California }\end{array}$ & ROV & $\mathrm{L}$ & $2005 \mathrm{Apr}$ & $394 \mathrm{~m}$ & $\begin{array}{l}\text { Gasca et al., } \\
2007\end{array}$ \\
\hline Haliscera sp. & $\begin{array}{l}\text { Scina spinosa } \text { Vosseler, } \\
1901\end{array}$ & N/A & $\mathrm{J}$ & $?$ & $\begin{array}{l}\text { Gulf of } \\
\text { California }\end{array}$ & ROV & $\mathrm{L}$ & 2006 Oct & $1263 \mathrm{~m}$ & $\begin{array}{l}\text { Gasca et al., } \\
2015\end{array}$ \\
\hline Haliscera sp. & $\begin{array}{l}\text { Scina uncipes Stebbing, } \\
1895\end{array}$ & N/A & A & $?$ & $\begin{array}{l}\text { Gulf of } \\
\text { California }\end{array}$ & ROV & $\mathrm{L}$ & 2006 May & $449 \mathrm{~m}$ & $\begin{array}{l}\text { Gasca et al., } \\
2015\end{array}$ \\
\hline $\begin{array}{l}\text { Pectis tatsunoko Lindsay \& } \\
\text { Pagès, } 2010\end{array}$ & $\begin{array}{l}\text { Mimonectes spandlii } \\
\text { Stephensen \& Pirlot, } \\
1931\end{array}$ & N/A & $\mathrm{JM}$ & SUM & Suruga Bay & ROV & $\mathrm{L}$ & $2002 \mathrm{Apr}$ & $1967 \mathrm{~m}$ & $\begin{array}{l}\text { Lindsay \& } \\
\text { Pagès, } 2010\end{array}$ \\
\hline
\end{tabular}

Stephensen \& Pirlot,

agès, 2010 